\title{
Avicenna's Use of the Arabic Translations of the Posterior Analytics and the Ancient Commentary Tradition*
}

\author{
Riccardo Strobino \\ Cambridge, UK
}

\begin{abstract}
In this paper I shall discuss the relationship between the two known Arabic translations of Aristotle's Posterior Analytics and Avicenna's Kitäb al-Burhän. I shall argue that Avicenna relies on both (1) Abū Bishr Mattăs translation and (2) the anonymous translation used by Averroes in the Long Commentary as well as in the Middle Commentary (and also indirectly preserved by Gerard of Cremona's Latin translation of Aristotle's work). Although, generally speaking, the problem is relevant to the history of the transmission of the Posterior Analytics from Greek through Syriac into Arabic, I do not intend to give a systematic presentation of the historical setting in which Aristotle's work became readily available to the Arabo-Islamic culture. My aim here is rather to isolate and discuss some pieces of evidence concerning the texts that seem to have been available to Avicenna.

In addition to that, I shall also provide evidence concerning the relationship with the Greek commentary tradition (in particular Philoponus and Themistius) that is likely to have influenced Avicenna in his discussion of Aristotle's theory of demonstration and scientific knowledge.
\end{abstract}

\section{Keywords}

Avicenna, Averroes, Posterior Analytics, Greek into Arabic, Greek Commentators

\section{Introduction}

This paper has the following rationale. There is an established literature on the topic of the Arabic translations of the Posterior Analytics. From the 1950s onwards it has become progressively clearer that two translations of Aristotle's

\footnotetext{
*) This study has been carried out in the framework of the project Major issues and controversies of Arabic logic and philosophy of language, run jointly by the Ruhr-Universität Bochum and the University of Cambridge with the financial support of the Deutsche Forschungsgemeinschaft and the Arts \& Humanities Research Council. I should thank Asad Ahmed, Amos Bertolacci, and Tony Street for their valuable comments on an earlier draft of this paper. All shortcomings are mine. Riccardo Strobino, Seminar für Orientalistik, Ruhr-Universität Bochum, D- 44780 Bochum, Riccardo.Strobino@rub.de.
} 
work were available: (1) Abū Bishr Mattā’s (d. 940) translation $^{1}$ and (2) a later anonymous translation used, along with the former, by Averroes in his Long Commentary (Sharh al-Burhān, partially extant in Arabic up to An. Post., A23, entirely in Hebrew and Latin), in the Middle Commentary (Talkhis al-Burhān, entirely extant in Arabic, Hebrew and Latin) and by Gerard of Cremona's Latin translation of the Posterior Analytics. ${ }^{2}$ As a matter of fact, scholars like MinioPaluello, Walzer, Gätje and Schoeler, Hugonnard-Roche, and Badawi ${ }^{-3}$ have focused extensively (and exclusively) on the relationship between these two translations and Averroes' texts: originally the case was made in connection with the Hebrew and Latin translations of the two commentaries (Minio-Paluello), and later on-after the rediscovery in MS. Berlin, Ms. Or. fol. 3176 of a long fragment of the Long Commentary and of the entire Middle Commentary-directly relying on the Arabic original (Gätje and Schoeler). ${ }^{4}$ In the context of such

1) See Aristotle, Mantiq Arisțū, edited by 'A. Badawī, 3 Vols. (Cairo: Maktabat Dār al-Kutub al-mișrīya, 1948-1952) [= Manțiq Aristū ]. Abū Bishr Mattā’s translation is already mentioned in Ibn al-Nadīm, Kitäb al-Fihrist li-l-Nadim, edited by G. Flügel, J. Rodiger and A. Müller, 2 Vols. (Leipzig: F.C.W. Vogel, 1871-1872). Cf. also F. Peters, Aristoteles Arabus: The Oriental Translations and Commentaries on the Aristotelian Corpus (Leiden: Brill, 1968).

2) The Arabic text is found in Averroes (Ibn Rushd), Sharh al-Burbän li-Arisțū wa-Talkhīs alBurbān, edited by 'A. Badawī (Kuwait: 1984), 45-153 [= Talkhis $]$ and 157-486 [= Sharb], respectively. The Latin translations of the Long Commentary I shall refer to throughout this article are found in Averroes, Aristotelis Opera cum Averrois Commentariis (Venetiis: apud Junctas, 15621574): Primi Voluminis Pars II Aristotelis Stagiritae Posteriorum Resolutoriorum Libri Duo cum Averrois Cordubensis Magnis Commentariis triplici interpretatione distinctis (Venetiis: apud Junctas, 1562), 1-668v (repr. Frankfurt am Main: Minerva, 1962, Vol. I Part. 2a) [= Giuntina, LC]. The Latin translation of the Middle Commentary is found in Averroes, Aristotelis Opera cum Averrois Commentariis (Venetiis: apud Junctas, 1562-1574): Averrois Expositio Media In Librum Demonstrationis Aristotelis (Venetiis: apud Junctas, 1562), 1-35v (repr. Frankfurt am Main: Minerva, 1962, Vol. I Part. 2b and 3) [= Giuntina, MC]. As for Gerard of Cremona's Latin translation of the Posterior Analytics, see Aristotle, Analytica Posteriora Gerardo Cremonensi Interprete, edited by L. MinioPaluello (Bruges-Paris: Desclée de Brouwer, 1954) [= AnPGC].

3) See L. Minio-Paluello, "Note sull' Aristotele latino medievale," Rivista difilosofia neo-scolastica 43 (1951): 97-124, and Id., "Praefatio," in Aristotle, Analytica Posteriora, viii-xxxiv; R. Walzer, "New Light on the Arabic Translations of Aristotle," Oriens 6 (1953): 91-142; H. Gätje and G. Schoeler, "Averroes' Schriften zur Logik: Der arabische Text der Zweiten Analytiken im Grossen Kommentar des Averroes," Zeitschrift der Deutschen Morgenländischen Gesellschaft 130, no. 3 (1980): 557-585; H. Hugonnard-Roche, "Averroes et la tradition des Seconds Analytiques," in Averroes and the Aristotelian Tradition, edited by G. Endress, J.A. Aertsen and K. Braun (Leiden: Brill, 1999), 172-187; 'A. Badawī, "Tașdīr 'āmm," in Averroes, Sharh al-Burhān li-Arisțū, in particular Section 5 "al-tarjama al-'arabìya al-wārida fì Tafsìr Ibn Rushd."

4) Note that the Middle Commentary is preserved in Arabic by a number of manuscripts, not only by the Berlin manuscript in which it survives alongside the fragment of the Long Commentary. See the list in Averroes, Middle Commentary on Aristotle's Posterior Analytics, critical edition by M.M. Kassem, completed, revised and annotated by C.E. Butterworth and A. Haridi (Cairo: alHay’a al-miṣrīya al-(āmma li-l-kitāb, 1982). 
discussions, Averroes' debt to the ancient commentary tradition was also called into play. ${ }^{5}$

By contrast, the relationship between these two translations and the bits of "Arabic Aristotle" that can be extrapolated on the basis of explicit and implicit quotations embedded in the text of Avicenna's Kitäb al-Burbān has attracted hardly any attention so far. ${ }^{6}$ In this respect, the Burhan is still, to a large extent, uncharted territory. This fact can be partially explained by the intrinsic difficulty in identifying and extrapolating from the continuous flow of Avicenna's text portions that can actually count as quotations from Aristotle, or as proper lemmata, to be compared with the two extant translations. Indeed, even when such bits come along with relevant markers (above all the expressions qāla l-mu'allimu l-awwalu or qila fi l-talimi $l$-awwali $\left.i^{7}\right)$ they often look much more like reelaborations, since they do not correspond to either of the two translations that have come down to us. ${ }^{8}$ Nonetheless, it can be argued with good reasons, as I shall endeavour to do in the following, (1) that Avicenna was familiar with both Mattās translation and the anonymous translation (unless we decide to assume an even stronger hypothesis that will be discussed below); (2) that in some cases,

5) The state of the art is summarized in Hugonnard-Roche, "Averroes et la tradition," 171-173. Cf. also 'A. Elamrani-Jamal, "Les Seconds Analytiques: Tradition arabe, traductions arabes, commentaires grecs, commentaires arabes," s.v. "Aristote de Stagire, Organon-Tradition syriaque et arabe," in Dictionnaire des Philosophes Antiques, edited by R. Goulet, Vol. 1 (Paris: CNRS Editions, 1989), $521-524$.

6) The only example is represented, to the best of my knowledge, by H. Eichner, "al-Fārābī and Ibn Sinā on 'Universal Science' and the System of Sciences: Evidence of the Arabic Tradition of the Posterior Analytics," Documenti e studi sulla tradizione filosofica medievale 21 (2010): 71-95; in A. Bertolacci, “Avicenna and Averroes on the Proof of God's Existence," Medioevo 22 (2007): 61-97 we find the suggestion that, as far as Fārābī and Avicenna are concerned, there is no proof that they knew the anonymous translation. The arguments I shall put forward here may justify, I believe, a revision of the claim in the case of Avicenna (and possibly in that of Fārābī, too). For a more systematic discussion of Avicenna's Burhān, see R. Strobino, "Avicenna on the Indemonstrability of Definition," Documenti e studi sulla tradizione filosofica medievale 21 (2010): 113-163.

7) These expressions are used to introduce quotations from Aristotle. Although they need not be necessarily regarded as proper lemmata, there are some cases in which the presence of additional markers like qawluhū ("his saying," or "when he says") followed by a short expression can hardly count as anything else. In such cases, there is no alternative other than assuming that what Avicenna is discussing is a passage or an expression literally taken from whatever he was reading.

8) Were we to take them literally, we would be forced to claim that yet another translation of the Posterior Analytics should have existed. What we find, however, is not enough in and of itself to prove such a conclusion (there might have been other translations, but it cannot be proven by appealing to such an argument). It might well be the case that Avicenna is sometimes quoting by heart or elaborating on the text or again, that he is quoting through the mediation of some other source. In addition to that, one should also keep in mind that passages might be the combined effect of a source text (maybe the result of a contamination of two translations) plus the contribution of the commentary tradition. I owe this point to Asad Ahmed who kindly shared his thoughts with me at a Cambridge conference on Arabic logic in November 2011. 
he is clearly using one translation against the other, or the other way around; and (3) that he also relies, in his work on the Posterior Analytics, on both Themistius' paraphrasis and Philoponus' commentary.

\section{Avicenna's Position: Method and Evidence}

The standard view has been for a long time, following Minio-Paluello's seminal work, that Averroes used the anonymous translation in the Long Commentary, whilst commenting on the first book of An. Post., as well as in the whole Middle Commentary, whereas he relied on Mattā's translation for the second book. However, after the discovery of the Berlin manuscript with part of the Arabic original of the Long Commentary, it has been proven that Mattā was already used by Averroes in the first book.

How does Avicenna position himself in this connection? In what follows I shall argue that

1. he uses Mattā while discussing the contents of the first book of An. Post.;

2. he uses the anonymous translation in at least one striking case in the second book (if he was using Mattā in that case, we would have to assume that he had a version of Mattäs text along with the glosses that accompany it in the Parisinus or some other text influenced by the latter ${ }^{9}$ );

3. he uses Mattā, along with the anonymous translation, for the second book.

4. he uses Themistius and Philoponus (and perhaps some other source in the ancient commentary tradition) for both the first and the second book.

I shall present seven passages. Three of them (Texts 1-3) compare Avicenna's text and the translations. The other four (Texts 4-7) deal with the relation to the commentators or other terminological problems.

I have checked Avicenna's texts taken from the Burbann against the following sources:

1. Aristotle ${ }^{10}$

2. Abū Bishr Mattās translation

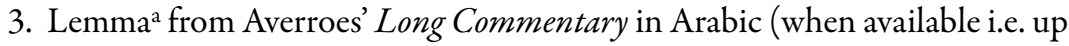
to An. Post., A23) ${ }^{11}$

9) The manuscript in question is the famous Paris, BNF Ar. 2346, which contains the Arabic Organon in its entirety.

10) Aristotle, Aristotle's Prior and Posterior Analytics: A Revised Text with Introduction and Commentary by Sir D.W. Ross (Oxford: Clarendon Press, 1949).

11) Bertolacci describes the organization of Averroes' Tafsir on the Metaphysics in the following 
4. Averroes' Middle Commentary in Arabic (relevant as a witness of the anonymous translation $)^{12}$

5. Averroes' Middle Commentary in Latin (Burana)

6. Lemma a from Averroes' Long Commentary in Latin

7. Lemma ${ }^{b}$ from Averroes' Long Commentary (Mantino when available, Burana and Balmes always)

8. Commentum from Averroes' Long Commentary (same Latin translations), if relevant

9. Gerard of Cremona's Latin translation of An. Post.

10. Gerard's Latin translation of Themistius' paraphrasis (which is known to derive from the Arabic)

11. Themistius' paraphrasis (Greek)

12. Philoponus' commentary (Greek).

In the analysis of each single passage that I am going to discuss, I shall include quotations from some or all of the above sources, according to their relevance to the context. The order will also vary according to the relative significance of the text.

Generally speaking, five possible configurations can be used to describe the relationship of the two translations with each other on the one hand, and Avicenna's quasi-lemmata on the other hand. The following categorization should not be taken too rigidly, because such similarity or dissimilarity come in degrees, but it can help us classify the cases in types:

terms "the translations upon which Averroes mainly relies for commenting on the Metaphysics are quoted in portions of variable length (Textus) at the beginning of the single units of the Tafsir. Each of the Textus, in its turn, is further divided into sentences (Lemmata), which are quoted a second time and commented upon by Averroes one after the other," see A. Bertolacci, The Reception of Aristotle's Metaphysics in Avicenna's Kitāb al-Shifā': A Milestone of Western Metaphysical Thought (Leiden: Brill, 2006), 13. The same is true of Averroes' Long Commentary on the Posterior Analytics. I shall adopt the following convention: the text of the main units (Textus) will be referred to as Lemma $^{a}$; the text of the subunits (Lemmata) in which the former is divided and repeated will be referred to as Lemma ${ }^{\mathrm{b}}$; the text of the commentary will be referred to as Commentum. In the famous XVIth century Giuntina edition (see above, f. 2), the multiple Latin translations are of Lemmata ${ }^{b}$ and of Commenta: three of them for roughly two-thirds of the first book (Mantino, Burana, and Balmes), the remaining two for the whole text (Burana and Balmes). In this connection, cf. also E.F. Cranz, "Editions of the Latin Aristotle Accompanied by the Commentaries of Averroes," in Philosophy and Humanism: Essays in honour of P.O. Kristeller, edited by E. Mahoney (Leiden: Brill, 1976), 116-128.

12) Averroes' Middle Commentary is not structured in the same way as the Long Commentary: it contains no proper lemmata, and the translation on which the work is based must be reconstructed indirectly. 
(a) Mattās text and the anonymous text are similar or identical:

(aa) Avicenna agrees with both

(ab) Avicenna agrees with neither

(b) Mattầs text and the anonymous text diverge clearly and significantly:

(ba) Avicenna agrees with or is closer to Mattăs translation

(bb) Avicenna agrees with or is closer to the anonymous translation

(bc) Avicenna agrees with neither

Each of the cases that are discussed below can be traced back to one of these alternatives.

Case (aa) is, to some extent, trivial and uninformative with regard to our present concerns, especially if we acknowledge that the anonymous translation may be quite likely a revision of Mattās translation. ${ }^{13}$ Where there is strong agreement or identity between the two, there is obviously no way for us to tell which is being used by Avicenna (or by Averroes, for that matter).

Cases $(a b)-(b c)$ are problematic, for they are compatible with different scenarios. No matter whether Mattā and the anonymous translation agree with each other $[=(a b)]$ or not $[=(b c)]$, if Avicenna has yet another text that differs from both, the origin of the discrepancy is difficult to establish. It might be due to the fact that he is following some other text or deliberately modifying a reading that is found in the two translations, if they agree, or from one of them only, if they do not. ${ }^{14}$

For such reasons, in a preliminary attempt to discuss this set of issues, I am going to be concerned with evidence relative to cases (ba), (bb), and to present an instance of $(b c)$ that I consider of special interest despite its difficulty (it is not entirely clear what the relationship between Mattã and the anonymous translation is like in the first place). ${ }^{15}$

Below is a summary of the passages that are reported in the textual appendix, with their respective significance.

The first three passages are about the relationship between Avicenna and the two translations. The last four are in support of the thesis that Avicenna is familiar

13) In support of this claim, see Minio-Paluello, "Note sull' Aristotele latino," 110-112, and Gätje and Schoeler, "Averroes' Schriften zur Logik," 567-568.

14) See Eichner, "al-Fārābī and Ibn Sīnā on 'Universal Science," 84-95 for evidence concerning the option that some divergences might be due to the influence of the commentary tradition (possibly even beyond Philoponus and Themistius).

15) I shall not deal, in this context, with type (ab), as I have not found so far absolutely compelling evidence concerning cases in which Avicenna clearly departs from one and the same (or strongly similar) text shared by the two translations. However, given the complex relations between the Burbān and its sources, this configuration should be nonetheless taken into account as a plausible alternative, which only further investigation should confirm or rule out. 
with both Themistius' paraphrasis and Philoponus' commentary, and possibly with even more.

Text 1. (An. Post., A2) [Case (ba) $]^{16}$

Avicenna uses Mattā’s translation against the anonymous translation, while commenting on the occurrence of the expression mu'talif in the definition of 'demonstration,' which is found only in the former.

Text 2. (An. Post., B1) [Case (bb)]

Avicenna uses the anonymous translation against Mattās: the terminology for the Aristotelian four-fold classification of scientific enquiries that he adopts is more easily understandable under this assumption. Alternatively, we would be forced to assume a stronger hypothesis, namely that he is directly acquainted with a tradition connected with the glosses to the Parisinus.

\section{Text 3. (An. Post., B2) [Case (bc) with Problems]}

Avicenna does not use Mattā in this case; he might be using with considerable freedom the anonymous translation; or he might be relying on a different branch in the transmission of one of the two texts (the problems raised by the presence of such discrepancies in the Latin translations of Averroes' Long Commentary seem to have gone unnoticed so far with respect to our present concerns, and would deserve further investigation, especially with regard to the role of Qalonymos b. Qalonymos' Hebrew translation, which was the source for all of the former). This would be confirmed, as is pointed out below, by the fact that the same variant is witnessed in the Latin translation of the relevant Lemma ${ }^{b}$ by Burana against all other witnesses of the text (in other words, Avicenna and Burana are the only witnesses of a contraposition bi-l-juz'i/in parte vs bi-l-kulli/in totum against the (by far) more frequent contraposition bi-l-juz'i/in parte vs 'alā l-ițläqi/simpliciter.

The remaining four passages deal with the relationship between Avicenna's text and the commentary tradition.

16) Another example of this kind is found in An. Post., A22 where Avicenna uses Mattā against the anonymous translation. In a famous passage in which Aristotle dismisses Platonic Forms, the Greek

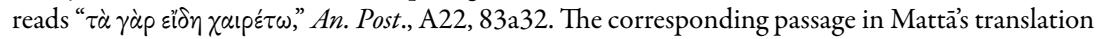
reads "fa-ammā l-suwaru fa-'alayhā l-salāmu," Mantiq Arisțū, II, 376.4, whereas the anonymous translation has "fa-ammā l-șuwaru fa-'alā dhikrihā l-'afä'u", (i.e. "mentioning the Forms is useless") Sharh, 451.3. Avicenna agrees with Mattā and seems to be quoting his translation almost verbatim “ammā l-șuwaru l-aflātūnìyatu, fa-'alayhā l-salāmu”, Burhān, III, 7, 233.1. 


\section{Text 4. (An. Post., B15) [Knowledge of Themistius' Paraphrasis]}

The passage proves that Avicenna has direct acquaintance with Themistius paraphrasis (the example is only in Themistius and Avicenna in relation to the same context: it does not occur in Aristotle or Philoponus).

\section{Text 5. (An. Post., B16) [Knowledge of Philoponus' Commentary]}

The passage proves that Avicenna has direct acquaintance with Philoponus' commentary (the example is only in Philoponus and Avicenna in relation to the same context: it does not occur in Aristotle or Themistius). ${ }^{17}$

Text 6. (An. Post., A13) [Gloss-Knowledge of Philoponus or of a Source in the Commentary Tradition Deriving from or Familiar with the Baghdaddi Glosses that are Transmitted in the Parisinus along with Mattäs Translation]

Two conclusions might be drawn from this example. A weaker conclusion counts as a further proof that Avicenna knows and makes use of Philoponus' commentary. A stronger conclusion, consistent with the former but with wider implications, is that with respect to this passage, Avicennas discussion is prompted not (or at least not merely) by knowledge of Philoponus' commentary-which is indeed the ultimate source-but is mediated by the gloss corresponding to this passage in the Parisinus containing Mattās translation of the Posterior Analytics (I mean the gloss directly, or an earlier source in the Arabic exegetical tradition of this passage, from which the gloss derives).

\footnotetext{
17) The same conclusion can be drawn with respect to another passage at least. In Burhän, IV, 1, Avicenna introduces a geometrical example (connected to the first proposition of the first book of Euclid's Elements) in his discussion of An. Post., B1-3. A similar example, in the very same context, is found only in Philoponus' commentary. The latter, commenting on An. Post., B3, 90b13,

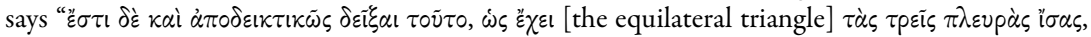

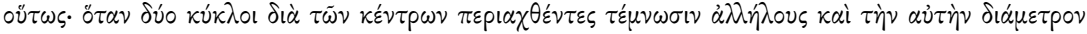

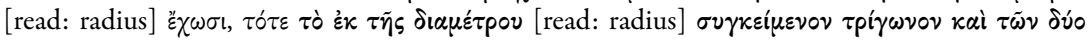

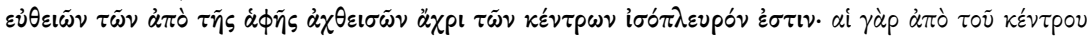

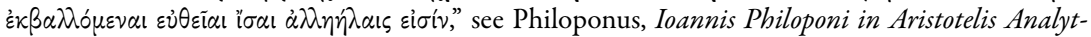
ica Posteriora Commentaria cum anonymo in librum II, edited by M. Wallies, CAG, Vol. XIII (Berlin: Reimer, 1909), 343.13-18; cf. also Philoponus (?), On Aristotle Posterior Analytics 2, translated by O. Goldin (London: Duckworth, 2009), 26-27. Avicenna's text reads "fa-yakünu l-bahthu

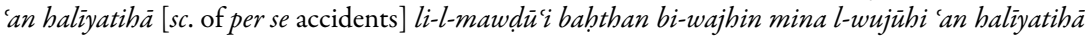
mutlaqan: ka-l-bahthi 'an halìyati l-muthallathi l-mutasāwì l-adlāi li-l-muthallathi l-mámüli

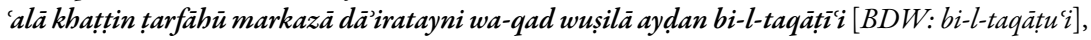
fa-buwa bahthun 'an halìyatibi fi-nafsibì. fa-bi-dhälika yulamu anna labū imkäna wujüdin," Burhān, IV, 1, 262.10-12.
} 
Text 7. (An. Post., B13) [Commentary Tradition: Philoponus and Themistius, and/or Another Source]

This passage has a number of interesting lexical remarks, with some philosophical relevance. Avicenna introduces the view of some mufassirüna and then describes how "the translator" (al-mutarjim) explains the meaning of an expression by pointing out the difference between the Arabic locution and its Greek counterpart. What is at stake in the example is the definition of a line, which, however, is not given in the corresponding passage of Aristotle's text. This suggests that the term 'translator' here is unlikely to refer to (one of) the translator(s) of the Posterior Analytics, but should rather be taken to stand for the translator of a commentary. Neither Mattā nor the anonymous translation (via Gerard of Cremona: the Arabic is not extant for this passage) have such locutions in the text.

The explicit definition of a line is given, by contrast, in the commentaries of both Themistius and Philoponus (as "a breadthless length"). The whole discussion, both in Themistius and in Philoponus, clearly follows the same line of thought that we find here in Avicenna.

In Avicenna, however, there is also an additional example, i.e. the case of quality and colour (which suggests that Eichner might be right in arguing in favour of the thesis that Avicenna's text could hint at unknown features of the ancient commentary tradition).

We have yet to hear the last word on this example, but it probably has to do with the Arabic translation of one of the two commentaries, or with yet another commentary: if not Themistius or Philoponus, it must be a tradition familiar with one of them or with a common source.

The above claims will be now argued for one by one in the following textual analysis.

\section{Textual Evidence}

Text 1. Definition of Demonstration [An. Post., A2-Burhān, I,7]

(case ba-translations differ, agreement with Mattā)

\subsection{Aristotle}

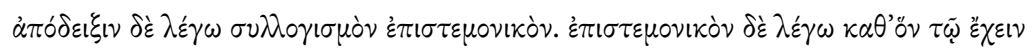
$\alpha \dot{\tau} \tau \grave{\partial} \nu \dot{\varepsilon} \pi \iota \sigma \tau \alpha \dot{\alpha} \mu \varepsilon \theta \alpha$.

(An. Post., A2, 71b17-19) 


\subsection{Abū Bishr Mattā}

wa-a'nī bi-l-burhāni l-qiyāsal-mu'talifa l-yaqinìa. wa-a'nì bi-l-mu'talifil-yaqinìyi lladhi na lamubü bimā huwa mawjüdun lanā. ${ }^{18}$

\subsection{Averroes, Long Commentary, Lemma ${ }^{\mathrm{a}}$ (Arabic)}

wa-a'nì bi-l-burhāni l-qiyāsa l-yaqinìya lladhì yu lamu bihì l-shay'u 'alà mā huwa 'alaybì.

(Sharh, 181.21)

\subsection{Averroes, Long Commentary, Commentum (Arabic)}

wa-qawlubū: "al-yaqin̄" huwa qawlun badala qawlihì: "l-qiyāsu lladhì ya'talifumin muqaddamātin yaqinìatin."

(Sharh, 182.11-12)

\subsection{Avicenna}

fa-l-burhānu qiyāsun mu'talifun yaqīnìyun.

wa-qad qüla fì tafsìri hādhā aqwālun. wa-yushbibu allā yakūna l-murādu bi-l-yaqìnìyi annahü yaqinīyu l-natījati; fa-innahū idhā kāna yaqinìya l-natījati fa-laysa huwa nafsubü yaqiniyan; wa-in amkana an yuj'ala li-hädhà wajhun mutakallifun law [BDW: wa] tukullifa ju'ila idkhāla "l-mu'talifi" fìhi hashwan mina l-qawli [BDW: l-maqüli], bal yakfí an yuquala qiyāsun yaqinìu l-natījati.

wa-yaghlibu 'alā zannīanna l-murāda bi-hādhä "qiyāsun mu'allafun min yaqinìyātin" wa-anna fì l-lafżi adnā tabrïfin. fa-l-yaqinìyatu idhā kānat fì l-muqaddamāti kāna dhālika hāla l-burhāni min jihati nafsìì. wa-idhä kānat fì l-natījati kāna dhālika hạlahū bi-l-qiyāsi ilā ghayribì. wa-kawnubū yaqiniya l-muqaddamāti

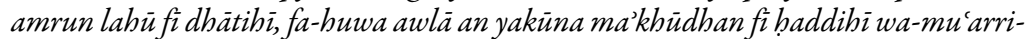
fan li-tabi'atibi.

(Burhān, I, 7, 78.15-79.4)

\subsection{Averroes, Middle Commentary (Arabic)}

wa-l-burhānu bi-l-jumlati huwa qiyāsun yaqīnìyn yufìdu 'ilma l-shay'i 'alà mà huwa 'alayhī fì l-wujūdi bi-l-illati llatī huwa bihā mawjūdun.

(Talkhīs, 49.10-11)

18) Note that in the Paris manuscript ' $i l m \bar{\imath}$ is recorded as a variant in an interlinear gloss above yaqini (see text 1.8 in the Latin translation of Averroes). 


\subsection{Averroes, Middle Commentary (Burana)}

Demonstratio autem in summa est syllogismus verus faciens acquirere scientiam de re secundum quod ipsi inest causa.

(Giuntina, $M C, 2^{\mathrm{v}} \mathrm{D}$ )

\subsection{Averroes, Long Commentary, Lemma ${ }^{\text {a }}$ (Latin)}

Demonstrationem vero dico syllogismum scientialem. ${ }^{19} \quad$ (Giuntina, $L C, 29^{\mathrm{r}} \mathrm{B}$ )

\subsection{Averroes, Long Commentary, Lemma ${ }^{\mathrm{b}}$ and Commentum (Mantino)}

Intelligo autem demonstrationem syllogismum verum, quo res eo modo, quo est, cognoscitur [...] et id quod dixit "veracem" est loco dicendi "syllogismum qui componitur ex praemissis veris."

(Giuntina, $L C, 29^{\mathrm{r}} \mathrm{B}-30^{\mathrm{r}} \mathrm{A}$ )

\subsection{Averroes, Long Commentary, Lemma ${ }^{\mathrm{b}}$ and Commentum (Burana)}

Volo autem per demonstrationem syllogismum verum, per quem cognoscimus rem, $\langle$ secundum $\rangle$ quod de ipsa aliquid [...] cum autem dixit "verus" idem est ac si diceret syllogismus compositus ex propositionibus veris. (Giuntina, $L C, 29^{\mathrm{r}} \mathrm{C}-30^{\mathrm{r}} \mathrm{A}$ )

\subsection{Averroes, Long Commentary, Lemma ${ }^{\mathrm{b}}$ and Commentum (Balmes)}

Intendo autem per demonstrationem syllogismum veracem, quo res scitur secundum quod est [...] et dum dicit "verus" intelligit syllogismum qui ex veris constat premissis.

(Giuntina, $L C, 29^{\mathrm{r}} \mathrm{C}-30^{\mathrm{r}} \mathrm{A}$ )

\subsection{Gerard of Cremona (Latin Translation of An. Post.)}

Per demonstrationem vero significo sillogismum compositum veridicum quo scitur res secundum quod ipsa est.

(AnPGC, 5.26-27)

\subsection{Themistius (Latin)}

Demonstratio non est nisi syllogismus compositus necessario creditus.

$(T P L, 247.37)$

\subsection{Themistius (Greek)}

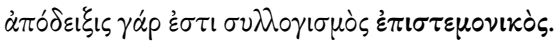

$(T P G, C A G, 5.17)$

19) See above, text 1.2 and f. 18. 
Analysis

In this passage Avicenna seems to depend on Mattās translation because he discusses a terminological issue that is understandable only with respect to that text and not to the one that is preserved in the anonymous translation. The definition of demonstration as a qiyās mu'talif yaqin̄i occurs explicitly only in Mattā. Avicenna seems uncomfortable with the use of the expression mu'talif, against which he would have preferred mu'allaf..$^{20}$ In his opinion this latter term would convey with more accuracy the sense of the definition: demonstration is a syllogism composed of premises that are certain, as he himself explains in the exegesis. The fact Avicenna takes yaqini to refer to the premises of a demonstration, not to its conclusion, accounts in a better way for the presence of mu'talif, whose inclusion in the definition otherwise would be, according to him, only a superfluous addition.

What is more, he considers the expression as a corruption or as an improper term. In the anonymous translation we find no counterpart to mu'talif in the Arabic transmitted by Lemma in Averroes' Sharh. The form i'talafa does occur in Averroes' commentary with the same sense of mu'allaf, but it does not seem to derive directly from the translation of the Aristotelian text he is commenting upon. Avicenna's discussion would not make much sense if he were simply to rely on the anonymous text as we find it in the lemma of Averroes' Sharb because it does not contain anything close to the definition that he intends to emend. ${ }^{21}$ If the anonymous translation is faithfully reflected by the text of Lemma ${ }^{\text {a }}$, neither $m u^{\prime}$ talif nor $m u^{\prime}$ allaf can be derived from it.

Interestingly, the locution mu'allaf, which Avicenna would expect to occur in the definition of demonstration, is possibly witnessed by the corresponding

20) On the use and meaning of the somewhat odd locution mu'talifsee D. Black, "Knowledge ( $i \mathrm{l} m$ ) and Certitude (yaqin) in al-Fārābī’s Epistemology," Arabic Sciences and Philosophy 16 (2006): 14, f. 5 (where the term, however, is read as mu'talaf). Black suggests that the term might count as a way to mirror in the Arabic the sense conveyed by the root of the Greek word $\sigma 0 \lambda-\lambda o \gamma / \sigma \mu o ́ s$ and regards the qualification mu'talaf as a lexical device to distinguish the use of qiyäs in the context of logic and philosophy from its kaläm counterpart. Another (I think less convincing) reading of this definition is found in J. McGinnis, "Avicenna's Naturalized Epistemology and Scientific Method," in The Unity of Science in the Arabic Tradition: Science, Logic, Epistemology and their Interactions, edited by S. Rahman, T. Street and H. Tahiri (Berlin: Springer, 2008): 132, where the whole expression is taken to mean "syllogism constituting (for mu'talif?) certainty."

21) Minio-Palluello provides, I believe, good arguments to reject the hypothetical objection that the lemmata (as is often the case in the commentary tradition) could have been a later insertion and should not necessarily be regarded as the very same text that the Commentator was looking at. At least in the case of the Long Commentary on Aristotle's Posterior Analytics, the text of the lemmata is provably the one Averroes was working on, see Minio-Paluello, "Note sull' Aristotele latino," 117-118. 
Latin term in Gerard of Cremona's translation where we find the word compositus, although nothing excludes in principle that the Arabic text that Gerard was translating already had mu'talif instead of the-perhaps more naturalmu'allaf. The Latin translation of Themistius' paraphrasis, which is known to derive from the Arabic and is also by Gerard, has the very same term compositus. Averroes' Middle Commentary, which usually shows a strong dependence on the anonymous translation (as opposed to Mattā), ${ }^{22}$ does not have either mu'talif or mu'allaf. ${ }^{23}$

Text 2. Taxonomy of Scientific Enquiries [An. Post., BI-Burhān, IV,1]

(case $\mathrm{bb}$ - translations differ, agreement with the anonymous text)

\title{
2.1. Aristotle
}

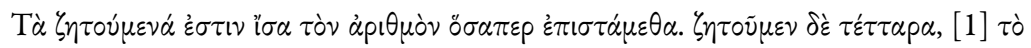

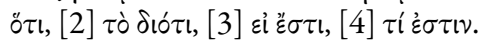

(An. Post., B1, 89b23-25)

\subsection{Abū Bishr Mattā}

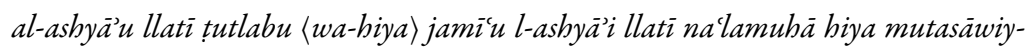
atun. wa-l-ashyāu llatì națlubuhā hiya arba'atun: ahadubumā [1] annahū yūjadu; wa-l-äkharu [2] li-mādhä; [3] in käna mawjūdan; [4] wa-mä huwa.

(Manțiq Arisțū, II, 407.8-10)

\begin{abstract}
[Marginal gloss (2)]
al-ashyāu l-mațlūbatu, minhā mufradatun, wa-minhā mu'allafatun: fa-l-mufradatu mithla Suqrāta, wa-hādhā l-himāri. wa-l-mu'allafatu mithla qawlinā:l-shamsu tankasifu.fa-l-mufradatu yutlabu min amrihä: hal hiya? thumma: mā hiya? wa-l-mu'allafatu yuțlabu min amrihā: hal hādhā mawjūdun li-hādhāe thumma: limā șāra hādhà mawjūdan li-hādhā? fa-l-ashyā'u idhan allatì tutlabu hiya arba'atun: [3] hal buwa; [4] wa-mā huwa; [1] wa-hal hādhā mawjūdun li-hādhā; [2] wa-limā hādhā li-hädhā.

(Manțiq Aristūu, II, 407, f. 2)
\end{abstract}

\subsection{Averroes, Long Commentary, Lemma ${ }^{a}$ (Arabic)}

Not extant

\footnotetext{
22) Again, see Minio-Paluello, “Note sull' Aristotele latino," 118-120.

23) Averroes, however, does have the inflected verb i'talafa (ya'talifu) in the Long Commentary, clearly with the meaning of "composed," with which the term is attested, see GALex, 294-295.
} 


\subsection{Avicenna}

al-mațālibu wa-l-ma'lümātu bi-l-talabi mutasāwiyatun [...] fa-innahā $[. .$.$] arba'a-$ tun: ithnāni dākhilāni fì l-hali-ahaduhumā [3] hal yüjadu l-shay'u, ay 'alā l-ițlāqi-wa-l-thānī [1] hal yüjadu l-shay'u shay'an? mithla annahü hal yüjadu l-jinsu murakkaban min ajzä'in ghayri mutajazzi'atin. wa-kullu wāhidin min mațlabay l-hali yatba'uhü matlabu [2] l-limā wa-yattasilu bi-dhālika mațlabu [4] l-mā. waammā mațlabu l-ayyi fa-mina l-tawābici li-matlabi l-mā. [...] wa-ammā mațlabu mā fa-innabù yatba'u l-mațlaba l-basīta min-mațlabay l-hali tab'an zāhiran [...] wa-yatba'u l-matlaba l-murakkaba min matlabay l-hali aydan 'alà wajhin mina l-wujūhi.

(Burhàn, IV, 1, 261.4-262.3)

\subsection{Averroes, Middle Commentary (Arabic)}

al-ashyāu l-mațlūbatu 'adaduhā bi-'aynihī 'adadu l-ashyā'i l-ma'lümati [...] wa-lmatlūbātu 'adaduhā bi-l-jumlati arba'un: ithnāni murakkabāni, wa-ithnāni basițāni.

fa-l-awwalu mina l-murakkabati huwa an națluba: [1] hal hādhā mawjūdun li-bādhä? [...] wa-huwa matlabu "hal" al-murakkabu.wa-l-matlabul-thāni mațlabu [2] "limā" kāna hädhä l-shay'u mawjüdan li-hädhä? [...] fa-hädhāni humā l-mațlabāni l-murakkabāni.

fa-ammà l-mațlübāni l-mufradāni, fa-ahadubumā huwa [3] țalabu wujūdi l-shay'i 'alà l-iṭlāqi là bi-bälin mā. wa-l-mațlūbu l-mufradu mithla an națluba: hal alkhalā'u mawjūdun, aw ghayru mawjūdin? wa-l-talabu l-thānì huwa lladhi naltami-

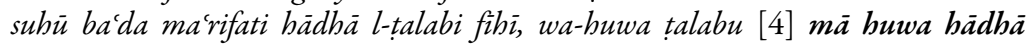
l-shay'u lladhi tabayyana wujūduhù.

(Talkhiṣ, 119.6-120.2)

\subsection{Averroes, Middle Commentary (Burana)}

Quod quaesitorum est idem numerus cum iis quae sciuntur, et hoc quoniam nos utique scimus ad ultimum ea quae quaeruntur. Et quaesita in summa sunt numero quatuor, duo composita et duo simplicia. Et prius quidem compositorum est, ut quaeramus [1] an hoc insit huic [...] quaesitum vero secundum est [2] quare hoc insit huic [...] Quaesita vero separata [note the Arabic mufradāni] ea sunt [3] quorum unum quaerit existentiam rei non in aliquo [...] Quaesitum vero secundum est per quod quaerimus scientiam quaesiti huius et est quaestio [4] quid est hoc.

(Giuntina, $M C, 25^{\mathrm{r}} \mathrm{A}-\mathrm{B}$ )

\subsection{Averroes, Long Commentary, Lemma ${ }^{a}$ (Latin)}

Quae quaeruntur sunt aequalia numero iis quaecumque scimus. Quaerimus autem quatuor, [1] quod, [2] propter quid, [3] si est, [4] quid est.

(Giuntina, $L C, 401^{\mathrm{r}} \mathrm{C}$ ) 


\subsection{Averroes, Long Commentary, Lemma ${ }^{\mathrm{b}}$ (Burana)}

Ea quae quaerimus et ea quae scimus sunt aequalia: quae vero quaerimus sunt quatuor, quorum unum est [1] quod est, et secundum [2] propter quid hoc, [3] si est, et [4] quid est. (Giuntina, $L C, 401^{\mathrm{r}} \mathrm{C}-401^{\mathrm{v}} \mathrm{D}$ )

\subsection{Averroes, Long Commentary, Commentum (Burana)}

Enuntiavit species quaestionis et dixit quod sunt quatuor: quarum una est [1] quod est, et altera [2] propter quid hoc, [3] si est et [4] quid est.

Et si res sit quemadmodum cecidit in hac translatione oportet quod intelligatur sermo ipsius "si est" quod sunt due species, si est ita in hoc, et si est simpliciter [...] [3] si est res aut [1] si est cum tali dispositione.

(Giuntina, $L C, 402^{\mathrm{r}} \mathrm{B}$ )

\subsection{Averroes, Long Commentary, Lemmab (Balmes)}

Res quae quaeruntur et res quas scimus coequantur. Res autem quas quaerimus sunt quatuor. Quarum una est [1] utrum sit et altera [2] cur sit et [3] an sit et [4] quid sit.

(Giuntina, $L C, 401^{\mathrm{r}} \mathrm{C}-401^{\mathrm{v}} \mathrm{D}$ )

\subsection{Averroes, Long Commentary, Commentum (Balmes)}

Enuntiavit quaesitorum species et dixit quod sint quatuor: quorum unum est [1] utrum sit, et alterum [2] cur sit, [3] an sit aut [4] quid sit.

Et si res sit prout cecidit in hac traductione expedit eius dictum intelligere, "utrum sit" esse duarum specierum, utrum sit sic talis et an sit simpliciter; et per haec duo fiunt quaesita quatuor: ambo enim quaeruntur adverbio utrum, ut [3] utrum res sit aut [1] utrum sit talis.

(Giuntina, $L C, 402^{\mathrm{r}} \mathrm{B}$ )

\subsection{Gerard of Cremona (Latin Translation of An. Post.)}

Res quas quaerimus et res quas scimus sunt res una eadem numero. Et quaestionum quidem numerus est quatuor; quarum una est [1] an hoc insit huic, et secunda [2] quare istud insit huic, et tertia [3] an hoc sit, et quarta [4] quid est hoc.

$(A n P G C, 64)$

\section{Analysis}

The passage is taken from Burhān, IV, 1, which corresponds in its entirety to An. Post., B1-3. The context that concerns us here in particular is the discussion of the number and types of scientific enquiries in B1. Avicenna gives a list that, in terms of content, is conceptually the same as the one we find in Aristotle 
but whose terminology departs from the latter in one relevant case. The four questions are formulated in different ways in Mattās text (which is closer to Aristotle) and in the anonymous translation, which for this particular portion of the text can be reconstructed from Gerard of Cremona's Latin version and from the Latin translations of Averroes' commentaries. Here Avicenna seems to be following the anonymous translation.

He presents the four questions and discusses, along Aristotelian lines, their mutual relationships with respect to the properties of middle terms involved in demonstrative syllogisms. His own vocabulary preserves the what-and why-questions, but characterizes the other two questions as if-questions (both in the existential case [3] and in the predicative case [1]). A fundamental distinction in the Aristotelian framework is the one between the question whether something is (i.e. if it exists absolutely) and the question whether something is something else (i.e. that something is something else, a case of predication). Both questions are labelled by Avicenna under the heading of if-questions ( hal basit and hal murakkab, respectively). The same terminology occurs in the anonymous translation indirectly transmitted by Gerard of Cremona's Latin text. Unfortunately, in this case we cannot make comparisons with the Arabic text of the corresponding lemmata and of the commentaries thereupon from the Long Commentary, because this portion of the original is not extant. But we do have valuable remarks from the Latin translations. Averroes, in particular, is aware of the existence of an alternative terminology (as opposed to the one that he receives from Mattā) in the other translation. The same terminology is found in Averroes' Talkhis, where the Aristotelian distinction between the if-question (existence) and the that-question (predication) is formulated in terms of simple if (hal basit) and compound if (hal murakkab), i.e. exactly in the same way as in Avicenna. The terminology of the Middle Commentary is known to derive from the anonymous translation, and not from Mattā.

It should be noted that there are two other places where the terminology found in Avicenna (and Averroes) is attested in a similar, albeit not identical form: (1) a gloss to Mattäs translation in the Parisinus formulates the Aristotelian if- and that-questions in terms of simple if- and compound if-questions, making use of the locutions hal mufrad and hal mu'allaf to characterize them; (2) al-Fārābī, in his Kitāb al-Hurūf, ${ }^{24}$ makes also use of hal to characterize both the existential and the predicative case.

To explain where Avicenna might have taken his terminology from we have therefore two main alternatives. A first, natural hypothesis, is that he takes it

24) This point was brought to my attention by S. Menn, "al-Fārābī’s Kitäb al-Hurū fand his Analysis of the Senses of Being," Arabic Sciences and Philosophy 18 (2008): 84-90. Cf. Al-Fārābī, Kitāb al-Hurüf, edited by M. Mahdi, Beirut: Dār al-Mashriq 1969), III, 228-231. 
directly from the anonymous translation (the claim is reinforced by the fact that the terminology in Averroes' Talkhiss, which in turn depends on the anonymous translation, is identical with that of Avicenna's Burbān). Otherwise, we should hypothesize that Avicenna was acquainted either with the gloss to Mattā’s text, or with Fārābī's terminology or with yet another source that was connected to one of the latter. ${ }^{25}$

One last remark is in order. The differences in terminology used to present the taxonomy of scientific inquiries are also regarded by Minio-Paluello as an example of the agreement between the text of the Middle Commentary and the text translated by Gerard, as opposed to the case of the agreement between the text found in the Long Commentary and Mattās translation. ${ }^{26}$ In the context of his argument, Minio suggests that the formulation in terms of a double if might depend on a misreading in the anonymous tradition in which a anna has been mistakenly taken for a in. This claim, however, should be rejected. We have independent evidence that the opposition between the two ifs is genuine and does not derive from a misreading of anna in favour of in: indeed such evidence is provided by the fact that the gloss, Fārābì, Avicenna and Averroes himself (in the Middle Commentary) all spell out the distinction of the two questions by using the word hal (basit/mufrad vs murakkab/mu'allaf).

Text 3. Terminological Distinction (in parte vs simpliciter/in totum) [An. Post., B2-Burhān, $I V, 1]$

(case bc with problems - translations differ, agreement with neither; agreement with Burana)

\subsection{Aristotle}

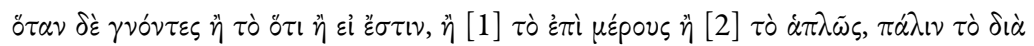

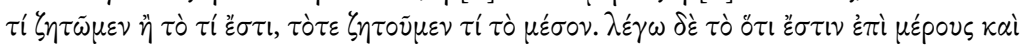
$\dot{\alpha} \pi \lambda \tilde{\omega} \varsigma$.

(An. Post., B2, 89b38-90a2.)

\subsection{Abū Bishr Mattā}

wa-matā 'alimnā immā annahū yūjadu aw annahū mawjūdun, immā [1] bi-l-juz'i wa-immā [2] 'alā l-iṭlāqi, wa-țlabnā mina l-ra'si: limā huwa? aw: mā huwa?fa-țalabunā hina'idhin innamā huwa an yutlaba mā huwa l-awsatu. wa-a'nì bi-qawlì

\footnotetext{
25) More complex combinations of circumstances should in fact be taken into account, but it is hard, at the present stage, to make conjectures about a hypothetical network of reciprocal influences involving the gloss(es), Fārābī, and the anonymous translation.

26) See Minio-Paluello, "Note sull' Aristotele latino," 118.
} 


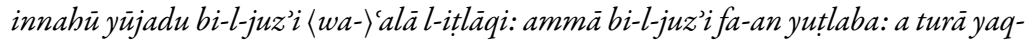
balu l-qamaru kusüfan? a'nì 'adamal-nüri, aw yatazayyadu tazayyudan. wa-dhälika anna țalabanà fì amthāli hādhihi immā anna l-shay'a mawjūdun aw ghayru mawjūdin. ammà 'alà l-ițläqi fa-huwa an națluba in kāna mawjüdan aw ghayra mawjüdin al-qamaru wa-l-laylu.

(Manțiq Arisțū, II, 409.5-11)

\subsection{Averroes, Long Commentary, Lemma ${ }^{a}$ (Arabic)}

Not extant

\subsection{Avicenna}

fa-qawlu l-mu'allimi l-awwali [1] "l-mawjūdu bi-l-juz'i" ya'nī bihì [om. 'Afifī] l-mawjūda shay'an mā. wa-[2] "l-mawjūdu bi-l-kulli" ya'nì bibì l-mawjūda 'alā

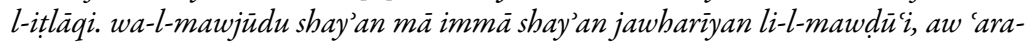
dan dhätīyan aw 'aradan khärijīyan.

(Burhān, IV, 1, 263.12-14)

\subsection{Averroes, Middle Commentary (Arabic and Latin)}

The corresponding passage does not discuss the terminological problem under consideration.

\subsection{Averroes, Long Commentary, Lemma ${ }^{a}$ (Latin)}

Quando autem cognoscentes aut quod aut si est, aut quod in parte aut simpliciter, rursus ipsum propter quid quaeremus aut quid est et tunc quaerimus quid est medium.

(Giuntina, $L C, 403^{\mathrm{v}} \mathrm{D}$ )

\subsection{Averroes, Long Commentary, Lemma ${ }^{\mathrm{b}}$ (Burana)}

Cumque quaerimus si est aut non est simpliciter quaerimus utique an videas quod sit aliquod medium ipsius aut non.

Cumque sciverimus si erit, aut si est, aut in parte aut in totum quaerimus de quaesito propter quid et quid est; quaestio utique nostra est ut quaeramus quid est terminus medius.

(Giuntina, $L C, 403^{\mathrm{v}} \mathrm{E}$ )

\subsection{Averroes, Long Commentary, Commentum (Burana)}

Hoc est quod significavit cum dixit "cumque sciverimus quod est vel quod est aut in parte aut simpliciter, quaerimus de quesito propter quid est aut quid est."

(Giuntina, $L C, 404^{\mathrm{v}} \mathrm{F}$ ) 


\subsection{Averroes, Long Commentary, Lemmab (Balmes)}

Quando autem quaerimus an sit aut non sit simpliciter, quaerimus numquid eius sit aliqua res media, necne. Et quando sciverimus quod erit aut sit secundum partem aut simpliciter, ulterius quaerimus ab initio cur sit et quid sit, et tunc quaerimus quid est illud medium.

(Giuntina, $L C, 403^{v} \mathrm{E}$ )

\subsection{Averroes, Long Commentary, Commentum (Balmes)}

Et hoc significavit quando dixit "et quando sciverimus quod erit aut sit secundum partem aut simpliciter ulterius quaerimus ab initio cur sit et quid sit."

(Giuntina, $L C, 404^{\mathrm{v}} \mathrm{F}$ )

\subsection{Averroes, Long Commentary, Lemma ${ }^{a}$ (Latin) ${ }^{27}$}

Dico autem quod aut si est in parte et simpliciter, in parte quidem, an deficit luna aut augetur. Si enim est aliquid aut non est aliquid in talibus quaerimus; simpliciter vero si est aut non est luna aut nox.

(Giuntina, $L C, 405^{\mathrm{r}} \mathrm{A}$ )

\subsection{Averroes, Long Commentary, Lemmab (Burana)}

Et intelligo, cum dico quod est in parte et simpliciter, in parte quidem cum quaeritur an suscipiat luna defectum, hoc est privatione luminis, aut augeatur augumento. Et hoc quoniam quaestio nostra in talibus est an res sit aut non sit; simpliciter vero cum quaerimus si est aut non est luna aut nox.

(Giuntina, $L C, 405^{\mathrm{r}} \mathrm{B}$ )

\subsection{Averroes, Long Commentary, Commentum (Burana)}

Postquam vocavit quaesitum compositum quod est in parte et vocavit simplex quod est simpliciter, coepit declarare haec nomina.

(Giuntina, $L C, 405^{\mathrm{r}} \mathrm{C}$ )

\subsection{Averroes, Long Commentary, Lemmab (Balmes)}

Intendo autem quando dico "secundum partem" aut "simpliciter," secundum partem quidem quia quaeritur "videsne lunam suscipere eclipsim, hoc est luminis defectum, aut crementum?" Nostra enim quaestio de tali est utrum res sit aut non sit; simpliciter autem an luna et nox sit aut non sit.

(Giuntina, $L C, 405^{\mathrm{r}} \mathrm{B}$ )

27) For this text I offer two distinct sets of lemmata and commenta from Averroes' Long Commentary: $3.6-10$ and $3.11-15$. 


\subsection{Averroes, Long Commentary, Commentum (Balmes)}

Postquam vocaverat quaesitum compositum illud quod est secundum partem et simplex quod est simpliciter, coepit explicare nomina. (Giuntina, $L C, 405^{\mathrm{r}} \mathrm{C}$ )

\subsection{Gerard of Cremona (Latin Translation of An. Post.)}

Sermo igitur noster "quaestio composita" et "quaestio simplex:" et composita quidem est sicut quaerimus an eclipsis que est privatio luminis insit lune et an additio insit ei (in hoc enim et huiusmodi non quaeritur nisi an predicatum insit subiecto an non insit ei); simplex autem sicut quaeritur an hec res ipsa sit an non sit, sicut luna et nox.

(AnPGC, 64.1-13)

\section{Analysis}

The question concerning predicative cases mentioned in the previous passage, i.e. the "if" in the second sense or, as it is also referred to, the compound if-question, which is the counterpart of the Aristotelian that-question, is labelled by Avicenna with the expression al-mawjüd bi-l-juz'. This captures the Aristotelian Greek $\dot{\pi} \pi \mathrm{i}$ u'́pous. In opposition to this way of characterizing the question of the "if" in which one asks whether something is something else as "in part," the other question, by means of which one asks whether something exists or not absolutely, is called a simple if-question or absolute question of the "if." The opposition $\dot{\varepsilon} \pi \dot{i}$

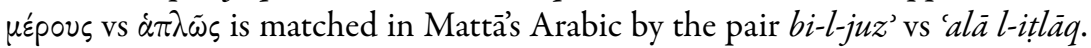

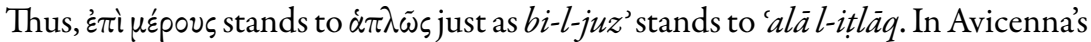
Burhān, however, in the analysis of this particular passage one element is formulated in quite a different way. Although the opposition is still understood in terms of absolute existence vs characterization of something by means of predication, the terminology adopted by Avicenna is bi-l-juz’ vs bi-l-kull.

The terminology in Averroes is the same as in Mattā, if we look at Lemmata $^{\text {a }}$ preserved by the Latin translation of the Long Commentary, but in one Lemma $^{\mathrm{b}}$ the opposition in parte vs in totum does occur once (see 3.7) in the translation by Burana (not in the one by Balmes, which consistently has the standard in parte vs simpliciter distinction throughout). The locution seems to be immediately forgotten in favour of simpliciter, so that in totum is no longer found even in Burana's translations of other texts where the terms in question are involved (see 3.8, 3.12, 3.13). Both translations are known to derive from the Hebrew version by Qalonymos b. Qalonymos (early XIVth century), but the circumstances of the transmission might turn out to be more complex than they were thought to be. In the Middle Commentary we find no trace of the distinction. 
The use of bi-l-kull in the opposition between bi-l-juz' and bi-l-kull, which Avicenna cleary has before him, might therefore derive from a source that resurfaces again (in a way which is yet to be understood) in Averroes' Long Commentary as is witnessed by one of its Latin translations. Since Avicenna shares the expression with Burana's Latin translation, this variant can hardly be dismissed as an innovation occurring accidentally in both of them at the same time.

Text 4. Themistius [An. Post., B15-Burhān, IV,8] (Knowledge of Themistius' Paraphrasis)

4.1. Plato

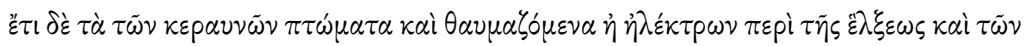

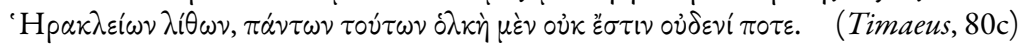

\subsection{Avicenna}

wa-inda Flāțūna jadhaba l-mighnātīisu wa-l-kahrabä’u wa-l-mihjamatu saba-

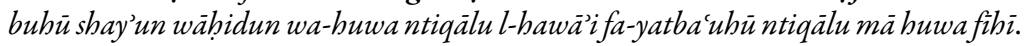

(Burhān, IV, 8, 319.11-13)

\subsection{Themistius (Greek)}

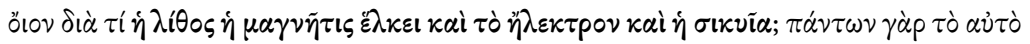

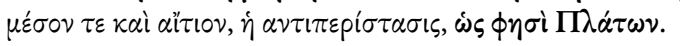

(TPG, $C A G, 60.1-2)$

\subsection{Themistius (Latin)}

Cuius exemplum est ut dicatur quare magnetes lapis attrahit ferrum et karabe et ventosa. Medium enim et causa in istis quaestionibus sunt unum et idem in sermone Platonis et est permutatio aeris.

(TPL , 309.5-6)

Analysis

This passage counts as a piece of evidence in support of the thesis that Avicenna was directly acquainted with Themistius' paraphrasis. The reference occurs only in Themistius and in Avicenna, who both mention Plato by name and offer the magnet and amber examples. No parallel is to be found in the corrisponding passage of An. Post., B15, 98a30 where the examples given are different. The same holds in the case of Averroes, who does not have this terminology either in the Long Commentary or in the Middle Commentary. 
The reference to Plato is correct and goes back to Timaeus, $80 \mathrm{c}{ }^{28}$

Text 5. Philoponus [An. Post., B16-Burhān, IV,8] (Knowledge of Philoponus' Commentary)

\subsection{Aristotle}

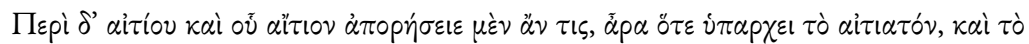

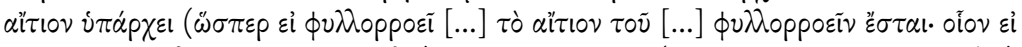

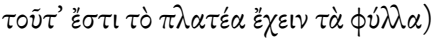

(An. Post. B16, 98a35-98b1)

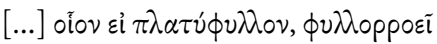

(ibid., 98b3-4)

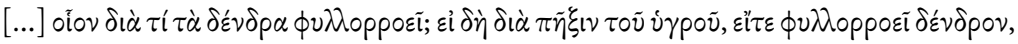

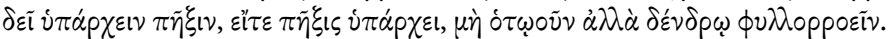

(ibid., 98b36-38)

\subsection{Abū Bishr Mattā}

wa-ammā fì l-illati, wa-l-shay'i lladhī l-illatu 'illatuhī, wa-l-shay'u lladhīl-illatu lahū, fa-qad yatashakkaku l-insānu fa-yaqülu: a turā matā wujida l-ma'lülu fa-l-illatu aydan mawjüdatun mithla annabü in kāna yanthiru waraqatun [...] fa-qad tūjadu layta shi'rī [...] 'illatu intithāri l-waraqi-mithālu dhälika in kānat hādhihi l-illatu hiya an yaküna waraquhü 'arìdan

(Mantiq Arisțū, II, 454.12-455.3)

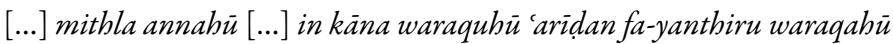

(ibid., 455.5-6)

mithālu dhālika: limā șāra l-shajaru yanthiru waraquhū? - in kāna dhālika li-n'iqädi l-rutūbati, fa-qad yajibu in natharat l-shajaru waraquhā an yūjada n'iqādu l-ruțūbati, wa-in wujida l-in'iqädu là li-kulli mà ttafaqa, läkinna li-l-shajari lladhì yanthiru waraquhü.

(ibid., 457.11-458.2)

\subsection{Avicenna}

wa-mithla kawni l-waraqi 'arịdan li-ntithäribī, fa-innahü sababun musawin li-lintithāri wa-in kāna baìdan, wa-l-qarību huwa sur'atu nqishāshi l-ruțübati l-māsikati, wa-huwa aydan musāwin, fa-yumkinu an yubayyana l-illatu bi-l-ma'tüli aydan kamā yubayyana l-ma'lülu bi-l-illati wa-yasìru l-bayānu dawran. fa-innabü in shi'nā qulnā inna [...] hädhihi l-shajarata 'arìdatu l-waraqi fa-yantathiru waraquhā, wa-hädhihi l-shajaratu ntathara waraquhü fa-hiya 'aridatu l-waraqi.

(Burhān, IV, 8, 320.9-14)

28) See Plato, Timaeus, 80c, in Platonis Opera, edited by J. Burnet, Vol. 8 (Oxford: Oxford University Press, 1903). 


\subsection{Philoponus (Greek)}

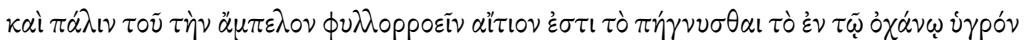

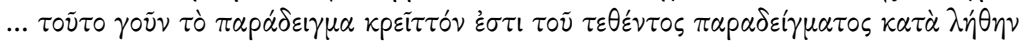

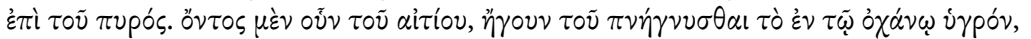

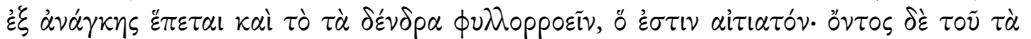

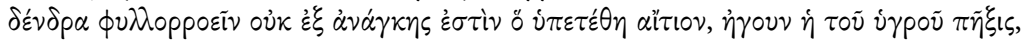

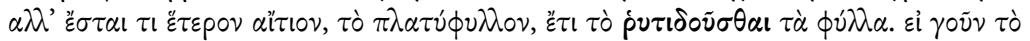

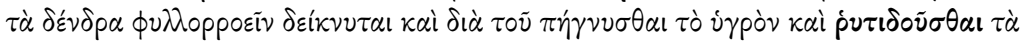

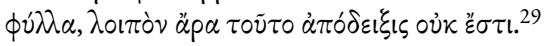

(PCG, CAG, 412.10-19)

\section{Analysis}

The passage speaks in favour of Avicenna's direct acquaintance with Philoponus' commentary. I have already discussed above one example (see f. 17) that goes along similar lines, and will present and discuss a more problematic case in the following Text 6 . I regard the present case as an additional independent proof. The relevant factor is the terminology employed in the example, where Aristotle is discussing a situation in which several things could be taken to be the cause of one and the same fact (here: the deciduousness of certain plants). The cause of a plant's shedding its leaves, we are told, is the congealing of the moisture in the juncture. The alternative cause mentioned by Aristotle is being "flat-leaved." The "shrivelling" ( $\tilde{v} \tau \iota \delta \circ \tilde{v} \sigma \alpha \mathrm{l}$, inqishāsh) is mentioned only in Philoponus and Avicenna.

In Averroes the situation is curious. In the Long Commentary, Lemma ${ }^{a}$ has roughly the same text as Aristotle. But the two Latin translations of Lemma ${ }^{b}$ make some confusion. Instead of "being flat [wide]-leaved" the term used is "frondium ariditas" (Balmes), maybe as a result of the similarity in sound with the Arabic 'arì u l-waraqi, and "siccitas foliorum" (Burana), with transposed meaning from one Latin term (ariditas) to the other (siccitas). Furthermore, in Balmes we have "causa autem quae est ipsum medium est quod vinea sit arida (!) [i.e. "dry", not "wide" as the Arabic 'arì w would suggest) frondibus" (Giuntina, LC, $536^{\mathrm{r}} \mathrm{C}$ ); and in Burana we find just the same error "et causa, quae est medium, est quoniam vitis est siccum foliis" (Giuntina, $L C, 536^{\mathrm{r}} \mathrm{C}$ ).

29) "And, again, a cause of [the fact] that a vine sheds its leaves is the thickening of the moisture in the juncture $[. .$.$] So when there is the cause, namely the congealing of the moisture in the juncture,$ there necessarily also follows [the fact] that the tree sheds its leaves, which is the effect. But when there is the shedding of the leaves of the trees, there is no necessity that there is what he supposed as the cause, namely the congealing of the moisture, but there will be some other cause, being flat-leaved, and besides that, the shrivelling of the leaves. So if it is proven that trees shed their leaves because of both the congealing of the moisture and the shrivelling of the leaves, it therefore follows that this is not a demonstration," see Philoponus (?), On Aristotle, 121). 
Text 6. Gloss on Philoponus [An. Post., A13-Burhān, III, 3] (Gloss-Knowledge of Philoponus or of a Source in the Commentary Tradition Deriving from or Familiar with the Baghdadi Glosses that are Transmitted in the Parisinus along with Mattä's Translation)

\subsection{Aristotle}

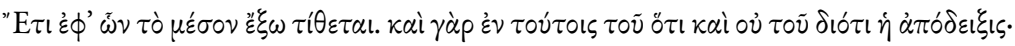

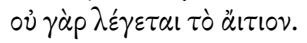

(An. Post., A13, 78b14-15)

\subsection{Abū Bishr Mattā}

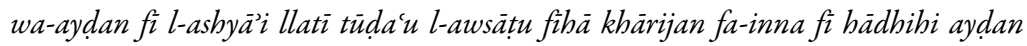
innamà yakūnu l-burbānu 'alā "anna" [for unni] l-shay'a là 'alā "limā huwa" idh kāna là yukbbiru bi-l-illati nafsì̄ā.

(Manțiq Arisțū, II, 350.16-351.1)

\subsection{Averroes, Long Commentary, Lemma ${ }^{\text {a }}$ (Arabic)}

wa-aydan al-barāhinu llatì yūda'u l-awsatu fìhä khärijan 'ani l-tarfayni, fa-inna hādhibi takūnu l-barāhinu fìhà 'alā "anna"l-shay'a. fa-ammà "limā huwa" fa-lā, idh kāna lam yu'ta bi-l-illati nafsibā.

(Sharh, 357.9-10)

\subsection{Avicenna}

wa-aydan fì l-ashyāi ilatì yūda'u l-awsațu [BDW: tüda'u l-awsātu] fìhā khärijan: innamā yakünu l-burhānu alà limā huwa idhā kāna ukbbira bi-l-illatinafsihā, fa-in lam yukhbar bihā nafsihà lam yakun burhāna 'alà limā bal 'alā an. [See below for the continuation]

(Burhān, III, 3, 204.16-18)

\subsection{Philoponus (Greek)}

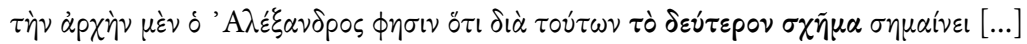

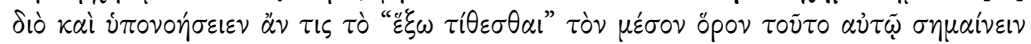

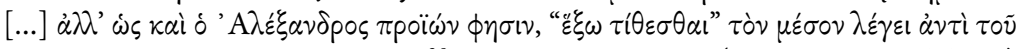

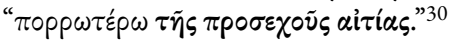

(PCG, CAG, 174.4-10)

30) "To begin with, Alexander says that by this he signifies the second figure [...] This is why someone might suppose that this is what the middle term being placed outside signifies for him [Aristotle]. [But the middle term being placed outside does not signify this for him] but, as Alexander says further down, he says that the middle term is placed outside instead of [saying that it is placed] further from the proximate cause." I wish to thank Richard McKirahan for sharing with me the translation of this passage right before the publication of Philoponus, On Aristotle Posterior Analytics 1.9-18, translated by R. McKirahan (London: Duckworth, 2012) for the ancient 


\subsection{Ibn Suwār’s Gloss to Abū Bishr Mattās Translation}

Abū Yahyā [al-Marwāzi] 'ani l-Iskandari qäla: yurìdu nizāma l-shakli l-thānì.

wa-Yahyà l-Nahwwì [John Philoponus] yaqülu: laysa l-amru ka-dhälika, bal innamā yuridu bibi l-illata l-baidata.

wa-Abū Bishr [Mattā] yazharu min qawlihì annahū yadhhabu ilāl-amrayni jamī'an.

wa-azunnu [Ibn Suwār] anna mā qälahū Yahyā l-Nahwì așaḥ̣u l-aqāwïli, wayashhadu bi-dhälika qawlu l-faylasüfi idh yaqūlu: "idh" [for in in Badawīs edition] kāna là yukhbaru bi-l-illati nafsibā." qäla lì l-shaykbu l-fädilu Yahyā ibn 'Adì: l-ḥaqqu mā qälahū Yahyā l-Naḥwì fì dhälika. ${ }^{32} \quad$ (Manțiq Arisțū, II, 351, f. 2)

\subsection{Avicenna (on the Gloss?)}

ammà lladhì là yakūnu fìhì illatun qarìbatun fa-qad qüla fì l-ta'limi l-awwali mà hādhā lafzuhū: "wa-aydan fì l-ashyāi llatī yūdacul-awsatu [BDW: tūda'ul-awsātu] fìhā khärijan: innamà yakūnu l-burhānu 'alà limā huwa idhā kāna ukbbira bi-l-illati nafsì̄à, fa-in lam yukhbar bihā nafsihà lam yakun burhāna 'alà limà bal 'alā an." wa-innamā ya'nì bi-l-illati l-illata l-qarïbata.

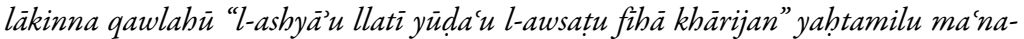
yayni: [1] ahaduhumà allà yakūna tartību l-ḅudüdi 'alà tartìbi l-shakli l-awwali bal 'alā tartībi l-thānì mathalan, fa-yakūnul-haddul-awsatu khärijan wa-là yakūnu u'tiya l-illatu l-qarībatu fìbi-kamā naqūlu fì l-shakli l-thānīinna l-jidàra là yatanaffasu li-annahü laysa bi-hayawānin, wa-kullu mutanaffisin hayawānun. wa-hādhā l-ta'wìlu azharu. wa-yakūnu innamā nusiba ilà l-shakli l-thānì li-annahū kamā 'alimta awlā bi-l-salbi. wa-hādhà yaqa'u fì l-barāhini l-sälibati akthara wa-in kāna qad yaqa'u fì l-müjibati.

fa-ammā [2] l-tafsìru l-thāni-wa-buwa l-așwabu wa-in lam yakun al-azharufa-huwa annahü ya'nī bi-l-awsați l-awsața fì l-qiyāsi wa-l-wujūdi jamīan, wabuwa l-illatu l-qarībatu, 'alā annahā mun'akisatun; wa-yakūnu ma'nā wad'ihì khärijan allā yakūna qad ruttiba fì ajzā̄i l-qiyāsi [BDW: ajzāa'a li-l-qiyāsi] bal turika min khärijin.

(Burbān, III, 3, 204.16-205.6)

commentators series edited by Richard Sorabji. The book was about to come out when this article was being prepared.

31) The emendation, which I take to be correct, is already in Walzer, "New Light," 100.

32) "According to Alexander he [Aristotle] means the second figure. But John Philoponus says: it is not like that, he rather means the remote cause. It is clear from Abü Bishr's words that he accepted both interpretations. But I [i.e. Ibn Suwār] believe that John Philoponus' statement is the soundest. In his favour are the words of the philosopher: 'Since $(i d h)$ he does not give the cause itself.' The excellent Shaikh Yahyā b. 'Adī said to me: 'What John Philoponus said about this passage is right', see Walzer, "New Light," 100. 
Analysis

This passage might suggest two different conclusions, which are again compatible with each other, as in the case of text 2 above, but of quite different strength. The first obvious conclusion is that Avicenna is familiar with Philoponus' commentary. The second, less obvious conclusion, is that he might be familiar with Philoponus (at least, although not necessarily only) through the mediation of a famous gloss that accompanies Mattās translation of the Posterior Analytics, ${ }^{33}$ in which both the opinion of Alexander of Aphrodisias and that of Philoponus are reported (see Walzer's translation, f. 32). In a difficult passage that has puzzled the interpreters since late Antiquity, Aristotle uses the expression $\dot{\varepsilon} \phi ' \tilde{\omega} \nu \tau \grave{\partial} \mu \dot{\varepsilon} \sigma \circ \nu$ $\ddot{\varepsilon} \xi \omega \tau i \theta \varepsilon \tau \alpha \iota$ to identify certain peculiar types of pseudo-demonstrations. How to understand the meaning of the locution, though, has been the object of some debate. An immediate option is that of considering "outside" to refer to the position of the middle term as a predicate, which would yield syllogisms in the second figure. But the real explanation, according to Avicenna, is that the remote cause is being referred to, in agreement with Philoponus.

\section{Text 7. Mutarjim [An. Post., B13-Burhān, IV,5] (Commentary Tradition:} Philoponus and Themistius, and/or Another Source)

\subsection{Aristotle}

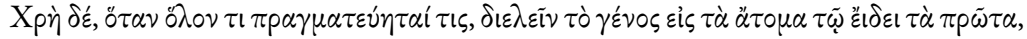

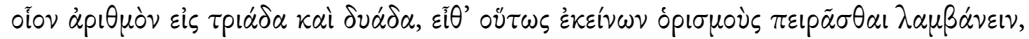

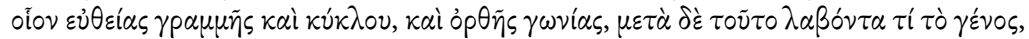

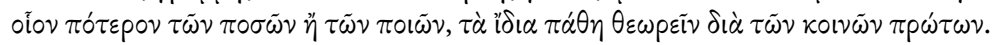

(An. Post., B13, 96b15-21)

\subsection{Abū Bishr Mattā}

wa-qad yanbaghì, matā qașadal-insānu ilà tạ̣dìdi jumlatin mā wa-kullin, an yuqassima l-jinsa ilā ghayri l-mutajazzi'ati l-uwali bi-l-naw'i-mithālu dhälika an yuqassima l-adada ilà l-thulāthīyati wa-l-thunā'ìyati; thumma yaltamisu an ya'khudha ḅudūda hādhayni wa-nazā̄iribimā-mithālu dhālika hạddu l-khațti l-mustaqimi, wa-haddul-dā'irati, wa-haddul-zāwiyati l-qā'imati. thumma ba'da dhālika idhā mā akhadha ayyumā huwa jinsuhü-mithālu dhälika: a turā huwa mina l-kammīyāti aw mina l-kayfìyāti? fal-nanzur ilà lawāzimibì l-khāsșīyati bi-tilka l-umūri l-ämmiyati awwalan.

(Mantiq Arisțū, II, 443.9-444.4)

33) The content of the gloss is discussed at some length in Hugonnard-Roche, "Averroes et la tradition," 175-176. 


\subsection{Avicenna}

fa-yajibu an natluba [BDW: tutlaba] jamī'a l-mabmulāti llatī tubmalu 'alaybī [sc. the genus] däkbilatan fì mahiyatihì, kānat awwaliyatan aw ghayra awwalìyatin [lahī add. 'Afïí]. fa-hina'idhin yukhraju laka haddu l-naw'i, wa-haddu jinsihi ma'an bi-subūlatin.

wa-ammä kayfa yukhraju dhälika fa-qad ju'ila mithälu hädhä fìl-ta'limil-awwali an yu'khadha [BDW: yūjadu] l-khattu l-mustaqimu wa-khatțu l-däirati wa-khattu l-qați l-munhani wa-khattu l-zäwiyati, mathalan al-qāimatu. fa-inna ttișāla kulli khatțin bi-khatțin immà 'alà l-istiqāmati, wa-immā 'alā l-inḥināì wa-l-istidārati wa-immà 'alà zāwiyatin.

fa-yakūnu l-khatțu l-mustaqimu yūjadu lahū annahū țūlun bilā arḍin, wa-l-nuqatu llatì tufradu fìhì taqa'u bayna nuqtatay țarfay hì alà muhādhätibā kulluhāiyyahumā. wa-l-qawsu țülun bilà ardin, wa-yumkinu an tüjada fìhi nuqtatun kullu l-khutūți l-mustaqimati llatī takhruju ilayhā minhu takūnu mutasāwiyatan. wa-l-mutahaddibu [BDW: munjadhib] 'alà zāwiyati țülun bilā 'ardin yuhịtu bi-saṭin wa-fìhi nuqtatun bi-l-fili yattasilu 'alayhā juz'ähī, fa-idhā hudhifa [BDW: hadhafta] khāssata [BDW: khasssiyata] kulli wähidatin min hädhibi baqiya mà baqiya [BDW: yabqā] mushtarakan wa-kāna haddan li-l-jinsi-wa-huwa annahü tulun bilā 'ardin.

thumma qüla fa-rjì ilà l-maqūlati llatì tuqālu 'alayhì wa-nzur fì lawāzimihì l-khāṣsati bi-tilka l-maqūlati awwalan, fa-inna lawāzima l-murakkabāti tustunbita min lawäzimi l-basāitịi. fa-ammā ba'du l-mufassirina fa-yaqūlu inna ma'nāhū in kāna l-shay'u kamman [om. 'Afifī] ka-l-khațti qulta "kammun [BDW: kam] țūlun bilā 'ardin," wa-in kāna kayfan [BDW: kayfìyatan] ka-l-lawni qulta "kayfun yakbriqu ['Afifi: yahriqu, BDW: yuharriku] l-mushiffa bimā huwa mushiffun bi-l-fili."

wa-ka-dhālika thumma inna l-mutarjima yaqūlu inna ma'nā hādhā annaka taqūlu fì lughati l-'arabi "tulun mà bilà 'ardinn", wa-fì lughati l-yūnānìyina là yasta'milüna lafzata "mā"l-dällata 'alā l-intishāri illā fî l-jawhari.

wa-ammā fì l-ashyā'i l-ukhrā fa-yasta'milüna badala lafzati "mā" sma l-maqūlati

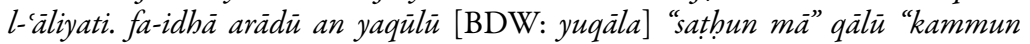
saṭ̂nun," aw "lawnun mä" qālü "kayfun lawnun."

wa-häulà'i ghayru munāza īna fì hādhā l-bābi li-annahum arbābu tilka l-lughati.

(Burbān, IV, 6, 308.12-309.8)

\subsection{Gerard of Cremona (Latin Translation An. Post.)}

Et necesse est homini, quando intendit diffinire summam (et hoc est quodlibet genus medium), ut intendat ad genus et dividat ipsum in species specierum eius sicut si dividat numerum in dualitatem et trinitatem, deinde comprehendat diffinitiones horum duorum et comparium utriusque. Et similiter, quando intendit diffinire lineam, accipit rectam et circularem, et quando intendit diffinire angulum, accipit 
rectum. Deinde post illud genus illius rei, et est aut ex quantitate aut ex qualitate, et venatur comitantia ipsum sibi propria, quorum unumquodque est communius eo ex diffinitionibus specierum.

$(A n P G C, 85.26-35)$

\subsection{Philoponus (Greek)}

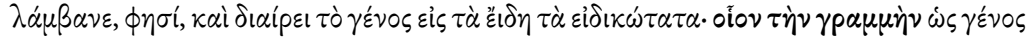

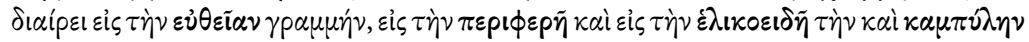

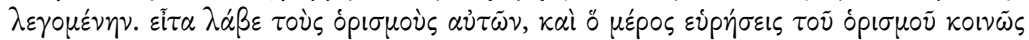

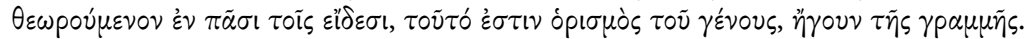

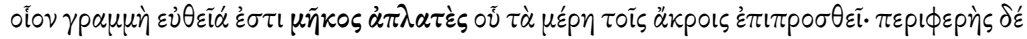

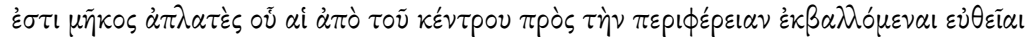

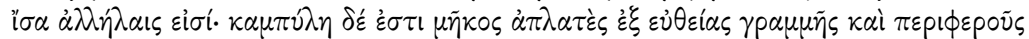

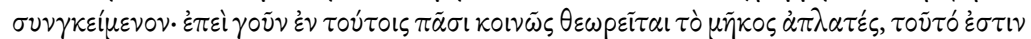

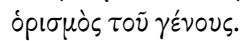

(PCG, CAG, 401,4-14)

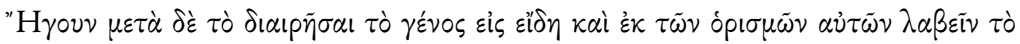

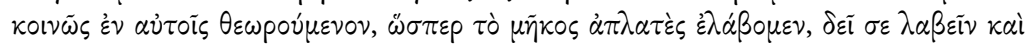

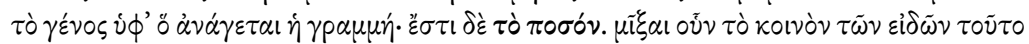

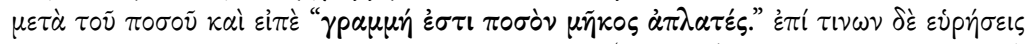

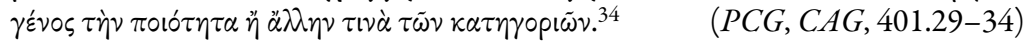

\subsection{Themistius (Greek)}

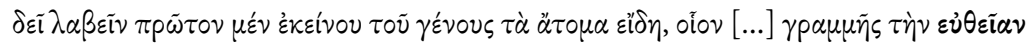

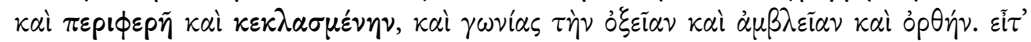

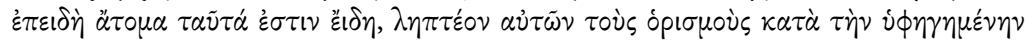

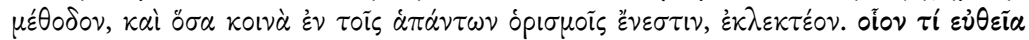

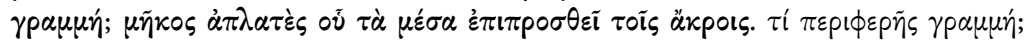

34) Commenting on $96 \mathrm{~b} 15$ Philoponus says "Now that he has taught a method by which you will discover the definitions of the most specific species, he teaches another by which one can discover the definitions of the genera. The method goes like that. Take the genus, he says, and divide it into the most specific species. For example, [taking] line as genus, divide [it] into straight line, circular, helix and the [line] that is called 'crooked.' Then take their definitions, and the part of the definition that you will discover to be observed common to all of the species is the definition of the genus, that is of line. For example, a straight line is a breadthless length of which the parts are in front of the extremities. A circular [line] is a breadthless length of which the straight lines that extend from the centre to the circumference are equal to each other. A crooked [line] is a breadthless length made up of a straight line and a circular line. So since 'breadthless length' is observed to be common in all of these, this is [the] definition of the genus" (transl. by O. Goldin, 96); later on, at 96b19, we read "in other words, after dividing the genus into species and taking from their definitions that which is observed in them to be common, just as we took breadthless length, so you must also take the genus under which line is classified. It is quantity. So bring together with quantity that which is observed to be common to the species and say 'a line is a quantity [which is] breadthless length.' For such things you will discover that the genus is quality or another of the categories," see Philoponus (?), On Aristotle, 97. 


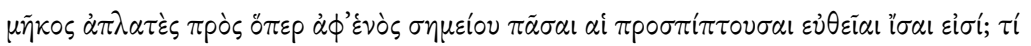

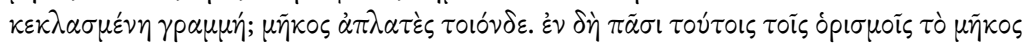

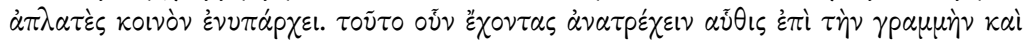

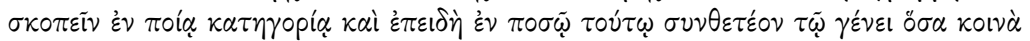

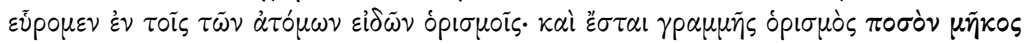
$\dot{\alpha} \pi \lambda \alpha \tau \dot{\varepsilon} \varepsilon$.

(TPG, CAG, 56.4-16)

\subsection{Themistius (Latin)}

In generibus autem quae dividuntur in species oportet ut ingrediamur hac semita. Sed oportet imprimis ut accipiamus quod est in illo genere de speciebus quae non dividuntur. Cuius exemplum quia, si est numerus, accipiemus binarium et ternarium. Nam illae species non dividuntur, quamvis sint species aliae praeter eas similes eis. Et si est linea, accipiemus rectam et circularem et flexuosam. Et si est angulus, accipiemus rectum, acutum et obliquum. Deinde si istae species non dividuntur, oportet ut accipiamus definitiones earum per illam viam quam narravimus, et quod invenimus in definitionibus omnium earum commune eligamus ipsum et colligamus. Cuius exemplum est ut consideremus quid est linea recta. Et inveniemus eam longitudinem sine latitudine et puncta tegunt extremitates eius. Deinde consideramus quid est linea circularis. Et invenimus eam longitudinem sine latitudine, et omnes lineae rectae, quae egrediuntur ad eam a puncto uno, donec concurrant ei, sunt aequales. Deinde consideramus quid est linea flexuosa. Et invenimus eam longitudinem sine latitudine cum aliqua dispositionum. In omnibus istis definitionibus invenitur sermo noster "longitudo sine latitudine" communis.

Cum ergo accipimus hoc, oportet ut redeamus ad lineam et consideremus in quo capitulorum adiecti ingrediamur et quia invenimus eam in quantitatis capitulo, tunc oportet ut componamus cum hoc genere omnes res, quas invenimus in hoc genere communes in definitionibus specierum quae non dividuntur. Fit ergo definitio lineae "quantitas longitudo sine latitudine," et ponuntur cum genere omnes res quae sunt communes in definitionibus specierum indivisibilium quae sunt sub eo.

$(T P L, 304.26-305.5)$

\subsection{Averroes, Middle Commentary (Arabic)}

wa-ammā in kāna l-maqșüdu taḥdidahū jinsan mutawassitan bayna l-anwā'il-akhirati wa-l-jinsi l-manzüri fìhi fa-l-sabilu fí dhälika an na'khudha hadda tilka l-anwä'i l-akhirati llatì yanqasimu bihā dhälika l-jinsu bi-tilka l-sabïli llatī wasafnā. fa-idhā wajadnā ḥadda kulli wāḥidin mina l-naw'ayni l-qasimayni asqatnā min dhälika mā yakhușsu wāhidan minhā, wa-akhadhnà l-mushtaraka, wa-adafnā ilayhī jinsa dhälika l-shay'i: immā kammìyata, wa-immā kayfìyata, wa-immā ghayra dhālika mina l-ajnāsi l-muhițati [possibly against the Latin translation] bi-dhälika l-shay'i l-áliyati.

fa-yakūnu l-mujtama'u min dhālika huwa hadda l-jinsi l-maqșüdi tahdìdahū, mithālu: annā idhā aradnā an nahudda [1] l-khațta, fa-innā na'midu ilà anwā'ihì 
l-akhirati wa-hiya: [2] l-khattu l-mustaqimu, [3] wa-l-mustadiru [4] wa-l-munhanī. thumma na'khudhu hadda kulli wähidin min hädhibi l-anwāi $i$-thaläthati bitilkal-țariqati.fal-nunzil annā wajadnā [def. 2] haddal-khațti l-mustaqimi annahū: "țülun bilā 'ardin" là yusnidu wasatuhū aträfahì inda l-nazari ilaybì 'alà stiqämatin.

wa-wajadnā [def. 3] ḩadda l-khațti l-mustadìri annahū "tülun bilà 'ardin" fì dākhilihì nuqtatun kullu l-khuțūti l-khārijati ilayhì minhā mutasāwiyatun.

wa-wajadnā [def. 4] hadda l-khațti l-munhanì annahü aydan "tūlun bilā 'ardin" mudāfan ilayhì khāsșatun ukhrā. fa-națlubu l-mushtaraka li-hädhihi l-hudüdi l-thalāthati, fa-najidubū fìhā qawlanā: "țülun bilā 'ardin"-fa-nudịfu ilaybījinsal-khutüți wa-huwa "l-kammu" fa-yakūnu [def. 1] haddu l-khatți l-mutlaqi annahü: "kammun labū tulun bilā 'ardin."

(Talkhīs, 141.6-19)

\subsection{Averroes, Middle Commentary (Burana)}

Si vero fuerit quod intendimus definire genus medium inter species ultimas et genus universale via utique in hoc erit ut accipiamus definitionem istarum specierum ultimarum per quas dividitur genus istud per hanc viam quam disposuimus. Cumque invenerimus definitionem utriusque secernimus ex hoc illud quod appropriatur uni ipsorum et accipimus communicans et complicamus ipsi genus istius rei, sive sit quantitas sive qualitas aut aliud ab hoc ex generibus que comprehenduntur in hoc superioribus. Et erit compositum ex hoc definitio generis, cuius intenditur definitio, ut in exempli, cum voluerimus definire lineam, consistemus super speciebus ultimis et est linea recta et circularis et reflexa. Deinde accipiemus definitionem uniuscuiusque istarum trium specierum per viam hanc et ponemus quod nos invenerimus definitionem linee rectae quod est "longitudo sine latitudine, cuius medium non removetur ab utriusque extremitatibus suis," cum consideratur secundum rectum. Et inveniemus definitionem lineae circularis, quod est "longitudo sine latitudine in cuius medio est punctus a quo omnes lineae exeuntes sunt equales" et inveniemus definitionem lineae reflexae, quod est "longitudo sine latitudine cum qua componitur proprium aliud" et investigabimus communicans his tribus definitionibus et inveniemus ipsis quod dicimus "longitudo sine latitudine" et complicabimus ipsi genus lineae, quod est quantitas et erit definitio lineae absolute quod est "quantitas habens longitudinem sine latitudine" et incessus noster ad definitiones generum a definitionibus specierum est res a consuetudine naturae, et hoc quoniam genera sunt composita et species simplices.

(Giuntina, $M C, 31^{\mathrm{v}} \mathrm{I}-\mathrm{M}$ )

\section{Analysis}

The discussion reported in the passage by Avicenna refers to something going on in the commentary tradition that we are not entirely privy to. While nothing resembling such a detailed analysis is to be found in Aristotle, there are analogous examples and arguments in Themistius and Philoponus, in particular the way in which the definition of a line is extracted from the definition of its species. The 
idea is to find the common element of a genus in the definition of the species that fall under it. This is already quite interesting in and of itself, because it shows once more Avicenna's familiarity with the commentators in this particular work. But it also suggests that the sources Avicenna is acquainted with might go beyond Themistius and Philoponus, since he makes use of examples that are nowhere to be found in the latter.

A second important point to be made with regard to this passage concerns the fact that Avicenna explicitly mentions "a translator" (probably the translator of the commentary he is reading) and indulges in a number of linguistic considerations. He is interested in the generalization of the problem and in discussing a terminological issue that is raised, according to what he says, by this unnamed translator. The issue has to do with the presence of the word $m \bar{a}$ in Arabic to qualify a category other than substance with a suitable linguistic construct, which does not sound natural to the translator as far as the common usage in Greek is concerned. While the expressions mufassir and sharb are occasionally used in the Burhān (once in this very same passage), the reference to a mutarjim seems to be a unicum in this work.

Additional evidence on the use of a similar terminology is found in Averroes. In the Long Commentary we can find only Aristotle's examples. In the Middle Commentary, on the other hand, the argument seems to reflect the influence of Themistius (more likely than that of Philoponus who has a richer terminology or, for that matter, of any other source that Avicenna might have been familiar with). As can be seen from the last two passages quoted above, Averroes follows exactly the same procedure suggested by Aristotle, spelled out in detail already in the commentators, and thereafter adopted by Avicenna, according to which the definition of a generic term can be extracted by taking out the common part shared in by the definitions of the specific terms that fall under that generic term.

\section{Conclusion}

The purpose of this paper was to present some hitherto neglected facts concerning the reception in Avicenna's Kitäb al-Burhān of the Arabic text of Aristotle's Posterior Analytics and the presence in it of uncontroversial traces of the ancient commentary tradition. These facts, in themselves, deserve considerable attention because they inform us about and reflect the complexity of the relationships between Avicenna's "Arabic Aristotle" and the two translations that, alongside other ancient sources-especially Themistius and Philoponus-he makes use of.

As to whether and how such factual elements-identity, similarity, convergence, divergence, difference with respect to both or neither of the two translations, the use of one against the other, and yet again, the extent of the influence of ancient commentators or that of an earlier Arabo-Islamic exegetical tradition- 
could be interpreted in a more general perspective, some suggestions can be put forward already at this stage, whereas some other questions will inevitably remain open. Although an accurate and exhaustive assessment of their general role will have to wait for a systematic investigation of all the identifiable lociparalleli (and of a clearer picture of the complex features involved in their later transmission through Hebrew and Latin translations), I think the significance of the relationships outlined above between Avicenna's Burhän and the Arabic versions of the Posterior Analytics and its "companions" cannot be overestimated.

My main conclusions can be summarized as follows:

1. Avicenna, like Averroes after him, already had access to both Arabic translations that are known to have existed (Abū Bishr Mattā’s translation and the anonymous translation). In particular, he provably makes use of

\subsection{Abū Bishr Mattās translation for the first book}

1.2. the anonymous translation for the second book

although no generalization can be made at this stage concerning the relative frequency of both.

2. Avicenna has knowledge of and is influenced by Themistius' paraphrasis and Philoponus' commentary.

3. Avicenna might have had knowledge of and have been influenced by other (unknown) sources from the ancient commentary tradition (in passages in which he is clearly drawing on the latter, he occasionally goes beyond what can be found in Themistius and Philoponus in terms of vocabulary and examples).

4. Avicenna might have had access to a source that is familiar with the glosses of the Parisinus (or to a copy of the manuscript itself, if Abū Bishr Mattās translation circulated in that form, or with the terminology attested in Fārābī’s Kitāb al- Hurüf). If this were to be the case, then the argument in support of the thesis that Avicenna uses the anonymous translation to comment on the second book of the Posterior Analytics would be slightly weakened (the terminology employed in the classification of scientific enquiries could be taken from the gloss, instead of deriving from the anonymous text, or also from Fārābī) but not ruled out. The same holds of the example from An. Post., A13, in which the explanation that Avicenna endorses might derive from a gloss to Mattā’s translation just as it could derive directly from Philoponus' commentary. Although assuming the stronger hypothesis, i.e. that Avicenna had access to the glosses, would explain two facts at once (the terminology used in B1 and the interpretations discussed 
to explain the passage in A13), I think this claim should be corroborated by more substantive historical evidence. I am therefore prudentially inclined to prefer the former alternative, i.e. the use of the anonymous translation and the hypothesis of Avicenna's direct acquaintance with Philoponus (especially because the latter is provable on independent grounds). Further research will hopefully shed some light on the question, if not settle it.

\section{References}

Sigla most frequently used in the article (full details in the corresponding bibliographical entries)

$\begin{array}{ll}\text { AnPGC } & \text { Analytica Posteriora Gerardo Cremonensi Interprete } \\ \text { CAG } & \text { Commentaria in Aristotelem Graeca } \\ \text { GALex } & \text { A Greek and Arabic Lexicon } \\ \text { Giuntina, LC } & \text { Aristotelis Stagiritae Posteriorum Resolutoriorum Libri Duo cum } \\ & \text { Averrois Cordubensis Magnis Commentariis } \\ \text { Giuntina, MC } & \text { Averrois Expositio Media In Librum Demonstrationis Aristotelis } \\ \text { PCG } & \text { Philoponus' Commentary on An. Post. (Greek) } \\ \text { TPG } & \text { Themistius' Paraphrasis of An. Post. (Greek) } \\ \text { TPL } & \text { Themistius' Paraphrasis of An. Post. (Latin) }\end{array}$

Primary Sources

Aristotle. Aristotle's Prior and Posterior Analytics. A Revised Text with Introduction and Commentary by Sir D.W. Ross. Oxford: Clarendon Press, 1949.

—. Analytica Posteriora Gerardo Cremonensi Interprete. Edited by L. Minio-Paluello. Aristoteles Latinus, IV, 3. Bruges-Paris: Desclée de Brouwer, 1954 [= AnPGC].

_.. Mantiq Arisțū. Edited by 'A. Badawī, 3 Vols. Cairo: Maktabat Dār al-Kutub al-miṣrìya, 1948-1952 [= Mantiq Arisțī] .

Averroes (Ibn Rushd). Sharh al-Burhān li-Arisțū wa-Talkhiṣ al-Burhān. Edited by 'A. Badawī, Kuwait: 1984 [= Sharh and Talkhīs, respectively].

—. Middle Commentary on Aristotle's Posterior Analytics. Critical Edition by M.M. Kassem. Completed, Revised and Annotated by C.E. Butterworth and A. Haridi. Corpus Commentariorum Averrois in Aristotelem I, a (5). Cairo: al-Hay’a al-miṣrīya al-'āmma li-l-kitāb, 1982.

-. Aristotelis Opera cum Averrois Commentariis. Venetiis: apud Junctas, 1562-1574: Primi Voluminis Pars II Aristotelis Stagiritae Posteriorum Resolutoriorum Libri Duo cum Averrois Cordubensis Magnis Commentariis triplici interpretatione distinctis. Venetiis: apud Junctas, 1562, 1-668 (reprinted Frankfurt am Main: Minerva, 1962, Vol. I Part. 2a) [= Giuntina, $L C]$.

- Aristotelis Opera cum Averrois Commentariis. Venetiis: apud Junctas, 1562-1574: Averrois Expositio Media In Librum Demonstrationis Aristotelis. Venetiis: apud Junctas, 
1562, 1-35 (reprinted Frankfurt am Main: Minerva, 1962, Vol. I Part. 2b and 3) [= Giuntina, $M C]$.

Avicenna (Ibn Sīnā). Al-Shifă', al-Manțiq, al-Burhān. Edited by A. 'Afifī. Cairo: al-Mațba'a al-amīìya, 1956 [= Burhän $]$.

—. Al-Burhān min Kitāb al-Shifä̀'. Edited by 'A. Badawī. Cairo: Maktaba al-nahḍa al-mișriya, $1954[=B D W]$.

Al-Fārābī. Kitāb al-Hurūf. Edited by M. Mahdi, Beirut: Dār al-Mashriq, 1969.

Ibn al-Nadīm. Kitāb al-Fihrist li-l-Nadìm. Edited by G. Flügel, J. Rodiger and A. Müller, 2 Vols. Leipzig: F.C.W. Vogel, 1871-1872.

Philoponus. Ioannis Philoponi in Aristotelis Analytica Posteriora Commentaria cum anonymo in librum II. Edited by M. Wallies. Commentaria in Aristotelem Graeca, Vol. XIII. Berlin: Reimer, $1909[=P C G]$.

-. On Aristotle Posterior Analytics 1.1-8. Translated by R. McKirahan. London: Duckworth, 2008.

-. On Aristotle Posterior Analytics 1.9-18. Translated by R. McKirahan. London: Duckworth, 2012.

Philoponus (?). On Aristotle Posterior Analytics 2. Translated by O. Goldin. London: Duckworth, 2009.

Plato. Platonis Opera. Edited by J. Burnet, Vol. 8. Oxford: Oxford University Press, 1903.

Themistius. Themistii Analyticorum Posteriorum Paraphrasis. Edited by M. Wallies. Commentaria in Aristotelem Graeca, Vol. V. Berlin: Reimer, 1900 [=TPG].

- Themistius' Paraphrasis of the Posterior Analytics in Gerard of Cremona's Translation. Edited by J.R. O’Donnell, Mediaeval Studies 18 (1956): 239-315 [= TPL].

\section{Secondary Sources}

Bertolacci, A. The Reception of Aristotle's Metaphysics in Avicenna's Kitāb al-Shifā': $A$ Milestone of Western Metaphysical Thought. Leiden: Brill, 2006.

"Avicenna and Averroes on the Proof of God's Existence." Medioevo 22 (2007): 61-97.

Black, D. "Knowledge ('ilm) and Certitude (yaqin) in al-Fārābīs Epistemology." Arabic Sciences and Philosophy 16 (2006): 11-45.

Cranz, E.F. "Editions of the Latin Aristotle Accompanied by the Commentaries of Averroes." In Philosophy and Humanism. Essays in honour of P.O. Kristeller. Edited by E. Mahoney. Leiden: Brill, 1976, 116-128.

Eichner, H. "Al-Fārābī and Ibn Sīnā on 'Universal Science' and the System of Sciences: Evidence of the Arabic Tradition of the Posterior Analytics." Documenti e studi sulla tradizione fllosofica medievale 21 (2010): 71-95.

Elamrani-Jamal, 'A. "Les Seconds Analytiques: Tradition arabe, traductions arabes, commentaires grecs, commentaires arabes." S.v. "Aristote de Stagire, Organon-Tradition syriaque et arabe." In Dictionnaire des Philosophes Antiques. Edited by R. Goulet, Vol. 1. Paris: CNRS Editions, 1989, 521-524.

Endress G. and D. Gutas eds. A Greek \& Arabic Lexicon. Vol. 1. Leiden: Brill, 2002 [= GALex].

Gätje, H. and G. Schoeler. “Averroes' Schriften zur Logik: Der arabische Text der Zweiten 
Analytiken im Grossen Kommentar des Averroes." Zeitschrift der Deutschen Morgenländischen Gesellschaft 130, n. 3 (1980): 557-585.

Gutas, D. Avicenna and the Aristotelian Tradition: Introduction to Reading Avicenna's Philosophical Works. Leiden: Brill, 1988.

Hugonnard-Roche, H. "Averroes et la tradition des Seconds Analytiques." In Averroes and the Aristotelian Tradition. Edited by G. Endress, J.A. Aertsen and K. Braun. Leiden: Brill, 1999, 172-187.

__. "Les Seconds Analytiques. Tradition syriaque." S.v. "Aristote de Stagire, OrganonTradition syriaque et arabe." In Dictionnaire des Philosophes Antiques. Edited by R. Goulet, Vol. 1. Paris: CNRS Editions, 1989, 520-521.

McGinnis, J. “Avicenna's Naturalized Epistemology and Scientific Method." In The Unity of Science in the Arabic Tradition: Science, Logic, Epistemology and their Interactions. Edited by S. Rahman, T. Street and H. Tahiri. Berlin: Springer, 2008, 129-152.

Menn, S. "Al-Fārābī's Kitāb al-Hurūf and his Analysis of the Senses of Being." Arabic Sciences and Philosophy 18 (2008): 59-97.

Minio-Paluello, L. "Note sull' Aristotele latino medievale." Rivista di filosofia neo-scolastica 43 (1951): 97-124.

. "Praefatio." In Aristotle. Analytica Posteriora Gerardo Cremonensi Interprete. Edited by L. Minio-Paluello. Aristoteles Latinus, IV, 3. Bruges-Paris: Desclée de Brouwer, 1954, viii-xxxiv.

Peters, F. Aristoteles Arabus: The Oriental Translations and Commentaries on the Aristotelian Corpus. Leiden: Brill, 1968.

Strobino, R. "Avicenna on the Indemonstrability of Definition." Documenti e studi sulla tradizione flosofica medievale 21 (2010): 113-163.

Walzer, R. "New Light on the Arabic Translations of Aristotle." Oriens 6 (1953): 91-142 (reprinted in Walzer, R. Greek into Arabic: Essays on Islamic Philosophy. Cambridge, MA: Harvard University Press, 1962, 60-113). 